\title{
THE TRAGIC WEDDING
}

\section{A. InTRODUCTORY}

WeDDING ritual in tragedy tends to be subverted. In explaining and arguing for this generalisation I hope also to shed new light on some of the passages deployed.

My starting point is the actual wedding ceremony. How did the Athenians of the classical period imagine that it was celebrated? Our evidence derives largely from contemporary drama and vase-painting. The picture presented by this evidence coheres very well in certain respects with that derived from other periods and places: Sappho, Catullus' imitation of the Greek, the lexicographers, and so on. For example, one important element that is found in the Attic and the non-Attic evidence alike is the ambiguity, for the bride, of the transition. The abrupt passage to her new life contains both negative and positive elements. On the one hand it is like the yoking of an animal or the plucking of a flower. ${ }^{1}$ It means isolation, separation from her friends and parents. ${ }^{2}$ It is an occasion of resentment and anxiety, ${ }^{3}$ comparable to death. ${ }^{4}$ And on the other

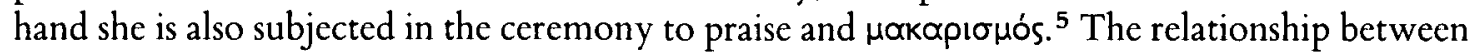
the negative and the positive tendency of the ritual is a delicate one: the negative tendency must not be denied, but it must of course eventually be overcome. For example, the negative image of nature destroyed may be met by the positive image of its taming and cultivation. ${ }^{6}$ The 'death' of the girl (or her abandonment of virginity) may be expressed by the sacrifice of a substituted animal. ${ }^{7}$ The wedding expresses not only the victory of a positive over a negative tendency, but also in a sense the victory of culture over nature. ${ }^{8}$ The wild animal is tamed; sexual union is legitimised; the field is ploughed. ${ }^{9}$ And because the wedding constitutes one of the two or three most fundamental transitions in the life of an individual, particularly perhaps for a woman, ${ }^{10}$ the failure to complete the transition is profoundly anomic. This failure, which may occur in various ways, is constantly explored by tragedy.

The most obvious form of this failure is of course death before marriage. Such a death is constantly imagined, notably in epitaphs, as a kind of marriage, notably (for the girl) with Hades. ${ }^{11}$ That is to say, a transition effected by nature (death) is enclosed by the imagination within a similar transition effected by culture (marriage). It is important to observe that this

1 See nn. 58, 62, 63, 64 below.

2 Sappho fr. 104(a) Voigt; Soph. Trach. 527-31, fr. 583; Theocr. 18.38-9; Poll. iii 42; Catull. 62.2 I-2, 32; Dracontius 6.92-5; Claudian Epithal. in Pall. I25; cf. e.g.

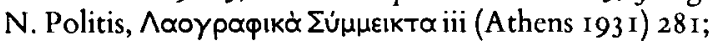
J. K. Campbell, Honour, family and patronage (Oxford 1964) I 2 I; Sourvinou-Inwood, below p. r40.

${ }^{3}$ Sappho fr. I1 4; Poll. iii 42; Theocr. 8.9 I; Schol. Theocr. 18.34; Plut. Lyk. Is, Mor. 289a; and for fifth century Attic vase-painting see Ian Jenkins in BICS xxx (1983), I37-45; Sourvinou-Inwood, below pp. I39I4I. Cf. also $n .2$ above, and Claudian Fesc. Honor. 4.34, de Cons. Stil. ii 357-8; Auson. Cento Nupt. 91 ff.; Varro Sent. I I Riese.

${ }^{4}$ See nn. 82-92 below; also Jenkins (n. 3) D. J. R. Williams in Ancient Greek and Related Pottery (Proc. Internat. Vase Symp. Amsterdam 1984), 279 (on $A R V^{2}$ 89.I3); Antiph. Soph. fr. 49 ( $c f$. G. Thomson, The prehistoric Aegean [London 1949] 338).

5 Praise: Sappho frr. 108, I 3 ; Ar. Pax I 350; Theocr. I 8.20-38; Himer. Or. I(9).19-20; Men. Rhet. 403.29 ff.; Ps. Dionys. Epid. 265, 270; Catull. 61.16 ff.; etc.; Politis

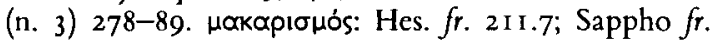
I 2; E. Alc. 918-19, Tro. 31 I-12, Hel. 375-6, 640,
1434-5, IA 1076-9, 1404-5, Phaeth. 240; Ar. Pax I 333 , Av. I722-5, 1759; Theocr. 18.16, 52; Od. iv. 208; Pi. Pyth. 3.88; Antoniad. Cret. 66 (Politis [n. 2] 284 n. 3). ${ }^{6}$ Notably at Catull. 62.38-56 (a poem largely Grcek in inspiration); $c$. n. 9 below.

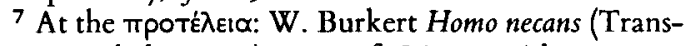
lation, Berkeley I983) 62-3; cf. IA 433 with 7I8-I9.

${ }^{8}$ See esp. James Redfield in Arethusa xv (1982), 1924 (add e.g. Ps. D.H. Epid. 262 (Radermacher) toũ $\mu \dot{v}$

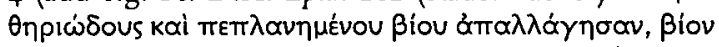

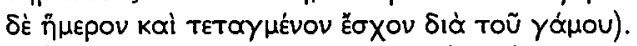

${ }^{9}$ See e.g. V. Magnien in $A C$ v (1936), $129-3 \mathrm{I}, 133-$ 4; J.-P. Vernant in Myth and society in ancient Greece (London 1982) I 38-9, I 50; M. Detienne, The gardens of Adonis (London 1977), I16-17; Redfield (n. 8); the

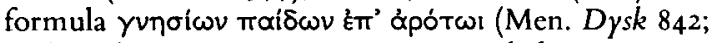
etc.); Aelian De Nat. An. xii 24; n. 58 below.

${ }^{10} \mathrm{Cf}$. Hipponax fr. 68 West: $\delta u^{\prime}$ í $\mu$ épå Yuvaı́ós

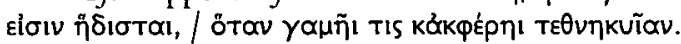

11 E.g. W. Peek Griechische Vers-Inschriften (Berlin I955) 658, I 162, I238, I55 I, I 553, 1989; ff. e.g. S. Ant. $8 \mathrm{Io}$; E. $I A{ }_{46} \mathrm{I}$; $c$. Aelian $f r$. so Hercher. For a striking recent example see TA NEA for I6.3.1987. 
cnclosure is facilitated by the presence in the wedding of elements associated with death, to some extent perhaps actual lamentation, but more importantly 'equivocal' elements common to the two rites of passage: ${ }^{12}$ in both wedding and funeral the girl is washed, anointed, and given

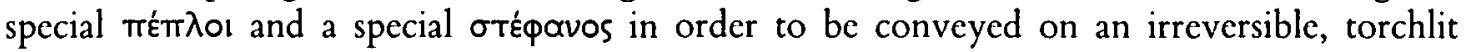
journey (on a cart) ${ }^{13}$ accompanied by song, and to be abandoned by her kin to an unknown

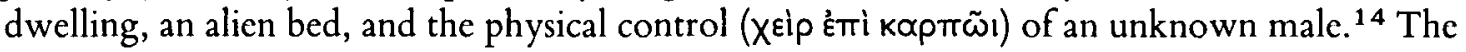
unmarried girl is buried in her wedding attire; ${ }^{15}$ she is imagined as a bride taken off by Hades; ${ }^{16}$ and so on. ${ }^{17}$ The wedding attire is of course not a mere symbol. It would have been worn in the actual marriage that she has been denied: ols $\gamma$ àp है हैuodov. ${ }^{18}$ The actual wedding may have been imminent. ${ }^{19}$ Indeed, this interpenetration of the two basically similar transitions is sometimes intensified to the point at which the girl (or sometimes the man) dies after preparations for the wedding have begun or even during the ritual itself. ${ }^{20}$ The surprising frequency (or at least the survival) of such cases is perhaps attributable to a tendency of the imagination to intensify the interpenetration. ${ }^{21}$ In these cases it is as if one of the negative elements in the wedding ceremony (marriage as death) has triumphed over the positive, as if the pattern of the wedding ceremony has been disrupted so as to turn into its opposite.

Tragedy is intensely interested in this kind of disruption. I will begin by noting threc cxamples of the death of an unmarried girl which is clearly associated with her imminent wedding (Antigone, Iphigeneia, Glauke). Secondly, as the centre-piece of the argument, I will discuss at length the case of the Danaids, in which the prevailing negative element is not the death of the bride but her hostility to the groom. Thirdly, in Section C, I will discuss examples of the death of a married woman imagined as the re-enactment of her marriage (Deianeira, Iokasta, Euadne, Medea). Finally, in Section D, I examine cases of extramarital sexual union imagined as marriage: i.e. a merely natural union is shaped by the imagination into a transition effected by culture $^{22}$ (Paris and Helen, Agamemnon and Kassandra, Herakles and Iole, Neoptolemos and Andromache). Reference will also be made to various other couples on the way. In all thesc categories the negative tendency of the ritual prevails.

\section{B. The Girl About To Be Married}

$\int \mathrm{I}$. The death of Antigone is presented by Sophokles in a manner suggestive of a wedding, in part with Hades or Acheron, in part with her betrothed Haimon. The place of her imprisonment

12 On wedding lamentation etc. see $\$ 4$ below and $n$. 4 above; on equivocal elements (and wedding laments) in Greece today see $M$. Alexiou, The ritual lament in Greek tradition (Cambridge 1974), 120-22. Note that such ambiguity within the wedding does not for the audience underlie the lament of Capulet (Romeo and Juliet iv 5.84-90): All things that we ordained festival / Turn from their office to black funeral: / Our instruments to melancholy bells, / Our wedding cheer to a sad burial feast; / Our solemn hymns to sullen dirges change, / Our bridal fowers serve for a buried corpse; (quoted by M. Alexiou and P. Dronke, Studi Medievali xii| 197 I| 83 I).

${ }^{13}$ In fact the corpse might be carried either on foot or on a cart (sec c.g. Beazley $A B V 346.7$ and 8, =E. Vermcule, Aspects of death in early Greek art and poetry $\mid$ Bcrkelcy $1979 \mid 20$, figs. is and I6). Equally unsurprisingly, the bridal pair sometimes went on foot (see c.g. Poll. ii 195).

14 Jescription of the funcral: Vermeule (n. I3) II$21 ; 1)$. C. Kurtz and J. Boardman, Greek burial customs (London 1971) ch. 7; Robert Garland, The Greek way of death (London 1985), ch. 3; of the wedding: W.
Erdmann, Die Ehe im alten Griechenland (Munich 1934), ch. 5; Daremberg-Saglio, Dictionnaire des Antiquités s.v.

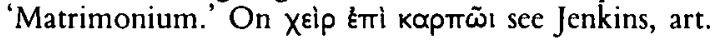
cit. n. 3 .

15 E.g. Peek (n. I I) 683, 1238; Alexiou (n. I 2) 230 n. 63; cf. E. Tro. $1218-20$.

${ }_{16}$ E.g. Peek (n. I1) 658, 1238, I553; Jenkins (n. 3).

17 E.g. Anth. Pal. vii I 85 (torches), 487 (bed), 489

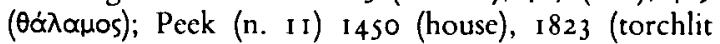
journey); $f$. e.g. S. Ant. 806-I6 (journey, bed).

18 Peek (n. II) 683.7-8.

19 E.g. Anth. Pal. vii. 29I, 568; Peek (n. 11) 988 , 1976, 1989; Ach. Tat. i 13.

20 Anth. Pal. vii I 82, I83, I88, 568, 6 10 (obviously imaginary), 711, 712; Peck (n. I1) 228, 1238, 1522, I 80I, I 825, I9 I0, I989. I9, 2038, cf. 878; A.R. iii 656-6r; Hor. C. iv 2.2 I; Heliod. ii 29.

${ }^{21}$ E.g. Peek (n. II) 1238 is an epigram which illustrates how easily the idea of death just before the wedding might arise from the practice of burying the unmarricd girl in bridal attire.

22 I.e. the same shaping as operates on the natural cvent of death (sec above). 
is both a tomb and a bridal chamber $(8 \mathrm{I} 6,89 \mathrm{I} ; c f .804,886,947)$. Hades ó maykoitas is taking Antigone off alive ( 8 I 0 f.) Less obviously, it should be noted that the hymn to "Epws that introduced Antigone's burial lament is appropriate to a hymenaial context. In particular, its theme is the power of sex in nature and in the cosmos, which was a tómos of the later wedding ceremony at least (see n. I 7 below), constituting praise of the mighty power that has brought the couple together. But here inasmuch as Haimon and Antigone are brought together in death (described in terms of sexual and marital union: see \$6), the tómos is in part reversed. Failure to realise this point has produced among critics puzzlement about the introduction of the theme and misunderstanding of its significance. ${ }^{23}$ As so often, deviation from what we expect arises from the presence of a tómos. Another example of this phenomenon is in fact provided by the 'marriage' in the tomb of Antigone and Haimon, which produces certain inconsistencies of plot. $^{24}$

2. Iphigeneia. We know several cases of girls before marriage traditionally lamenting for, or offering sacrifice, their hair, or libations to, a mythical young person who had died a virgin. ${ }^{25}$ Surely this mythical death is at least partly an expression of the death associated with the marital separation from maidenhood. The mythical figure embodies, albeit indirectly, the loss experienced by the bride, and provides an object for her emotions. It appears therefore that the subversion of the marital transition is a feature of myth. It is not invented by tragedy, though tragedy exploits it and probably extends its scope.

This is particularly clear in the case of Iphigeneia, who combines these two forms of substitute death (of a mythical maiden, of a sacrificial animal). In one version she is actually sacrificed to Artcmis, in another she is replaced by an animal (a hind, or a bear). The substitution of (or perhaps the metamorphosis into) a bear is reported by Phanodemos of Athens, ${ }^{26}$ and is clearly related to the importance of Iphigeneia and Artemis at Brauron, where young girls

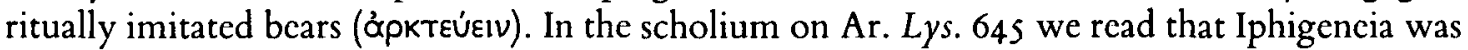

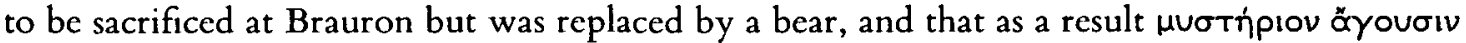

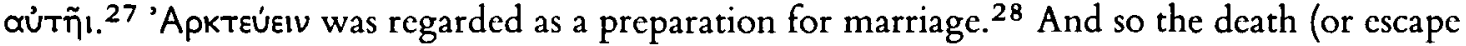
from death) of Iphigencia scems to have been, at least in part, an expression of the association of death with the loss of girlhood in marriage. Wilamowitz regarded the luring of Iphigeneia to Aulis by the prospect of marriage as inessential to the story ('zuthat zu der eigentlichen Geschichte') and guessed that it was an innovation by the poet of the Kypria. ${ }^{29}$ The question of who made the 'innovation' is unanswerable. But what we can say is that the 'innovation' was unlikely to have been absolute: like most unnecessary innovations, it was probably a development of an existing theme, namely that of Iphigeneia as bride. It is of interest here that in one version she was actually married to Achilles and had a son by him. ${ }^{30}$

In Euripides' Iphigeneia in Aulis the marriage to Achilles for which she is summoned by her father is of coursc only a device to encompass her sacrifice. But the persistent presentation of this sacrifice in terms of marriage is due only in small part to the needs of the deception. The normal

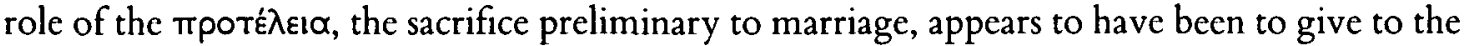
deity the life of an animal as a substitute for the life of the bride (n. 7 above). The rumour in the

${ }^{23}$ E.g. K. von Fritz in Philologus lxxxix (1934), 1933, reprinted in Antike und moderne Tragödie (Berlin 1962), 227-40; R. P. Winnington-Ingram, Sophocles, an interpretation (Cambridge 1980), 92-8 (similar to the failure to see that Antigone laments because it is her funcral: Seaford in $C Q$ xxxiv (1984), 254).

24 Notably in the bchaviour of Haimon: the inconsistencies are described by Tycho von Wilamowitz, Die Dramatische Technik des Sophokles (Berlin 1917) 21-3 (". . . Man sieht also deutlich, dass es dem Dichter von vornherein feststeht, dass Haimon in Antigone's Grabe Selbstmord begehen wird. Er überlegt sich genau so wenig wic der Zuschauer, wie und wozu er hineinge- kommen sein kann, und denkt nicht daran, das noch besonders zu motivieren'); and of. 36 with $773-80$.

${ }^{25}$ E.g. Hdt. iv 34; Pausan. i. 43.4; Plut. Arist. 20; Pausan. ii.32.1-4 (and E. Hipp. 1425-7).

${ }^{26} \mathrm{FGrH}_{325}$ (FI4(a) and (b)) (fourth cent. B.c.).

27 Cf. e.g. E. IT I 450 ff., and in general Brelich (n. I09) $24 \mathrm{I}-78$.

${ }^{28}$ Krateros FGrH 342 F9; Schol. Ar. Lys. 645; Burkert (n. 107) 263.

${ }^{29}$ In Hermes xxviii (1883), 250 $=K l$. Schr. vi 196 .

30 Nikander ap. Anton. Lib. 27 ( $f$. E. IA I355-6, 940); Lykophr. Alex. I 83, 324; Duris FGrH 76 F88. 


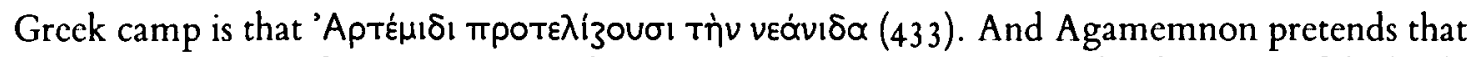

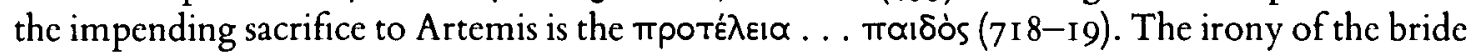

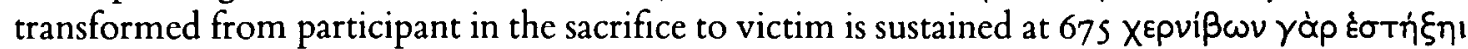

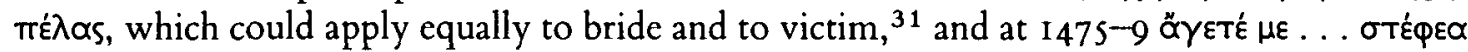

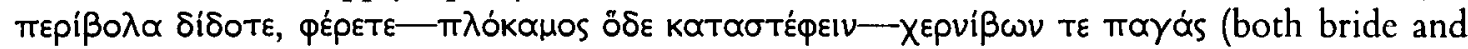

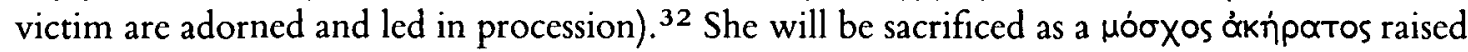

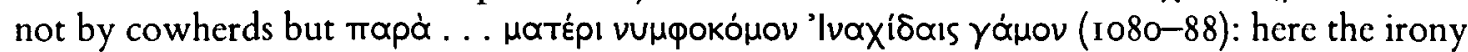
deploys a traditional comparison of the bride to a young animal leaving her mother. ${ }^{33}$ As in Aeschylus (see (9a), the death of Iphigeneia in her mpoté $\lambda \varepsilon 1 \alpha$ is not imagined but real. The negative element prevails.

Secondly, the arrival and final departure of Iphigeneia are presented in a manner evocative of the wedding. The elements of a normal wedding particularly relevant here are the

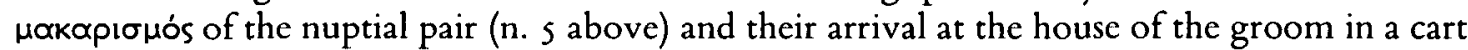
accompanied by the mother of the bride and other women. ${ }^{34}$ The moment of this arrival was a poignant stage, often depicted in Attic vase painting, ${ }^{35}$ in the transition of the bride to her new life, for it was here presumably that she was abandoned by her kin.

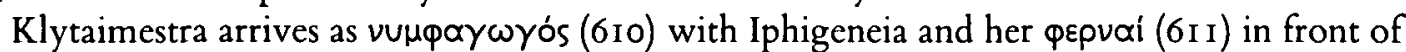

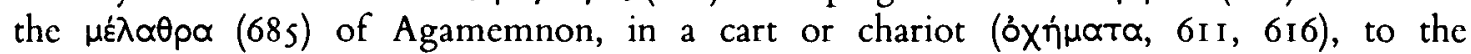

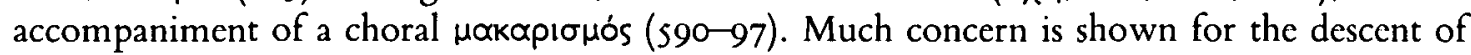
Iphigeneia from the chariot $\left(61_{4}-16\right) .{ }^{36}$ In the subsequent dialogue Agamemnon speaks of a

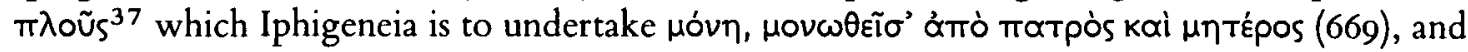
which she takes to mean that she is to live in another household. He then bids her farewell, $\chi \omega \dot{\rho}$ eı

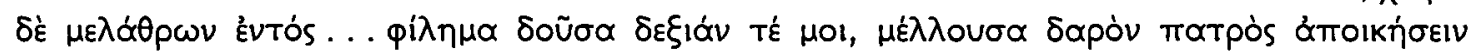
Xpóvov (678-80), and disguises his grief as that felt by a father at the marriagc of his daughter (688-90).

The next episode, in which Klytaimestra meets with Achilles and discovers the truth from the old man, is followed by a choral song celebrating the marriage of Peleus and Thetis. The aptness of this theme is obvious. The offspring of the marriage was Achilles; and it forms a

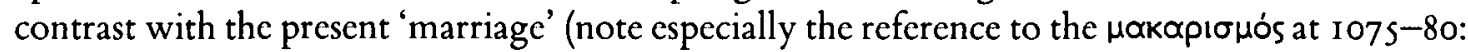

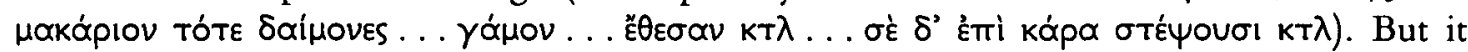
should also be noted that the practice of referring to a paradigmatic mythical or divine marriage secms to have been a practice of the contemporary wedding ceremony. ${ }^{38}$

The arrival of the Greeks to take Iphigeneia to her death produces the prospect of a scene familiar from certain descriptions of the wedding, the bride torn from the embrace of her mother $(1367,1460) .{ }^{39}$ Finally, the very last words of Iphigeneia evoke the predicament of the

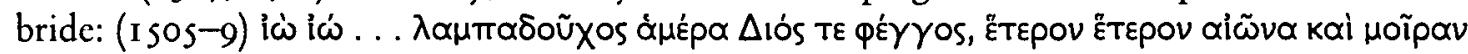

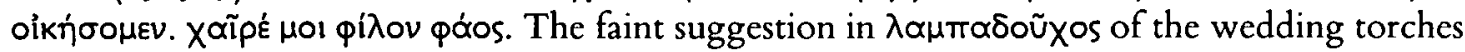

31 Cf. I 479, i $518, I T 58$ etc., and a similar ambiguity at A. Ag. 1036-8 (cf. $\left.\int \mathrm{ro}\right)$. Cf. also $I A$ ro80-88.

${ }^{32}$ For other parallels between marriage and sacrifice see J.-P. Vernant (n. 9) ch. 7; H. P. Foley in Arethusa Xv (1982), I59-80 (on the $I A$; a longer version in Ritual irony [Ithaca and London 1985 ] ch. 2).

${ }_{33}$ Seaford in Hermes cxiv (1986), 50-4; Sappho fr. I04(a); S. Trach. 527-30.

${ }^{4}$ IA 732; Schol. E. Tro. 3 I 5; Ov. Ep. 8.96; Nonn. Dion. 46.304; and the vase-paintings referred to in $n .27$. I find that the evocation of the wedding by the chariot is suggested also by Foley, Ritual irony 70-1.

35 Daremberg-Saglio (n. 14) s.v., 'Matrimonium' $1652-3$.

${ }_{36}$ There may well be much (early) interpolation or rewriting in this scene (D. L. Page, Actors' interpolations in Greek tragedy [Oxford I934] I60-9); but even (early) interpolated lines are not necessarily thereby excluded from our argument, which is not concerned with the personality of Euripides.

${ }^{37} \mathrm{Cf}$. below $\lceil 9 \mathrm{a}$.

38 Ar. $A v$. I73 I-44; Sappho fr. 44 (if hymenaial), $c f$. fr. 2 I 8 Voigt; Men. Rhet. 400-02 (includes Peleus and Thetis), etc.; Ps. D.H. Epid. 262; Claudian ix and Sidon. Ap. xiv (Peleus and Thetis); of. Catull. 64. Note also the popularity of the wedding of Peleus and Thetis in vasepainting, e.g. on a nuptial lebes, $A R V^{2} \$ 85.33$.

${ }^{39}$ Catull. $62.2 \mathrm{I}-2$ (surely based on a Greck model); cf. Sappho fr. I04; S. Trach. 527-3 I; E. Hec. 90-1, 2079, 418, 6I I-I 2; Plut. $L \gamma k$. 15; Politis (n. 2) $281 . f$. IA 1087. 
of which Iphigeneia has been deprived ${ }^{40}$ is strengthened by the subsequent suggestion of a change of dwelling place. ${ }^{41}$

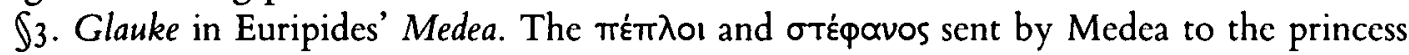
Glauke arc a wedding gift, contributing to the traditional eủ $\delta$ a $\mu$ ovi $\alpha$ of the bride (952-8). They are donned by the bride, who then admires herself in the mirror ${ }^{42}$ But they turn out to be "AI $\delta \alpha$

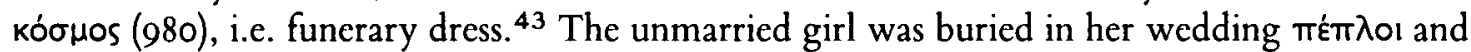

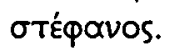

In the wedding of Glauke the association of the wedding kóonos with death has become a

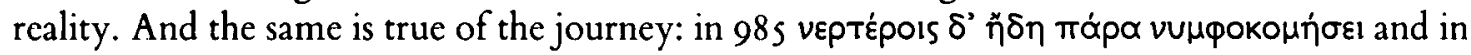

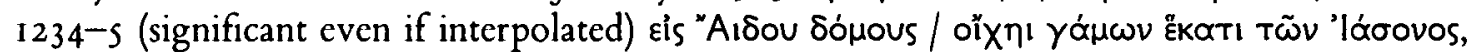
the destination of the bride's journey is the house not of her husband but of Hades. ${ }^{44}$ The association with death, one of the negative tendencies which in a normal wedding would be overcome in the rituals of transition and incorporation, has in the tragedy emerged as a triumphant reality.

\$4. The Danaids. Aeschylus' Suppliants presents two central, closely related, and unresolved problems. Firstly, is the aversion of the Danaids to marriage in general or to marriage with their cousins in particular? Numerous passages may be deployed to support each alternative. ${ }^{45}$ Secondly, on what is the aversion based? On the one hand, for Thomson, ${ }^{46}$ the conflict is between the rule of exogamy and the principle embodied in the Attic law of the heiress, by which heiresses without brothers could be claimed in marriage by their kin, so as to kecp the estate within the family. At the other extreme, Garvie ${ }^{47}$ maintains that 'we must look for the Danaids' motivation purely in their own character, and not in any simple obedience to a supposed moral or social principle'. Most recently, Friis Johansen and Whittle (henceforward FJW), while accepting the importance of the Attic law for evaluating the action of the Aegyptiads, insist that the Danaids do not in fact invoke the principle of exogamy or denounce the principle of endogamy. ${ }^{48}$ And so what motivates them? Here, FJW, while stressing the importance of the violence of the Aegyptiads, nevertheless implicitly admit puzzlement. ${ }^{49}$

It seems to me that progress on this front can be made only by the adoption of a new perspective. The attitude of the Danaids resembles in several respects the attitude associated with the Greek bride or her female companions, but taken to an exotic extreme. We are of course hampered in this comparison by the scarcity of direct evidence for the attitude and experience associated with the bride in fifth-century Attica. However, the coherence in various respects of the evidence for wedding ritual from different times and places ${ }^{50}$ is such that the cautious use of evidence from one area to complement evidence from another is not necessarily illegitimate.

The Danaids, lamenting and fearful of isolation from their kin, claim to have a kapoí $\alpha$ which

40 The absence or the extinguishing of the wedding torch was a tómos of the death-instead-of-marriage theme (see above; e.g. Anth. Pal. vii i 85 ; Bion r.87; Daremberg-Saglio [n. I4] s.v. 'Hymenaios'), and may be associated, as it seems to be here, with the darkness of Hades (e.g. Peek [n. I t ] 804). On the association of $\phi \tilde{\omega}$, and especially torchlight, with $\sigma \omega t \eta p i \alpha$, see Fraenkel on A. Ag. 522, Thomson on A. Ag. 522, 935-7I.

41 Meaning lifetime, alw'v might easily refer to the (new) lifetime that begins at marriage: E. Or. 603, Med. 243, Su. $1005(\$ 7 \mathrm{~d})$, Alc. 475. For Moĩpa and marriage sce Ar. $A v$. 1734; Poll. iii 38. And $c f$. Antiph. Soph. fr.

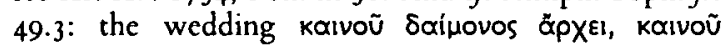
Tótuou.

${ }^{42} \mathrm{~A}$ scene depicted in Attic vase-paintings (e.g. Beazley $A R V^{2}$ I 476.3).

${ }^{43}$ Cf. e.g. E. $H F$ 562, Ba. 857. Cf. also the attention paid to Pentheus's dress (Med. I I6I-2 with $B a .928-34$, I 165-6 with 937-8). In CQ 37.1 (1987), 76-8 I suggest that Pentheus too is looking at a mirror.

${ }^{44} C f$. nn. I I-I 7 above.

45 A. F. Garvie, Aeschylus' Supplices: play and trilogy (Cambridge 1969), 221; H. Friis Johansen and E. W. Whittle, Aeschylus: the Suppliants (Copenhagen I980), i $30-4$.

${ }_{46}^{4}$ Aeschylus and Athens ${ }^{2}$ (London 1946), ch. 16.

47 (n. 45) 221.

48 (n. 45 ) i $34-7$.

49 'The reader may, at his own risk, take the themes of general aversion to marriage, ú $\beta p ı$ in the Aegyptiads and legally prescribed endogamy as suggesting various motives for the Danaids' flight from their cousins, but the function of these themes in Supp. (and perhaps in the trilogy as a whole) is only that of placing the action in a complex and shifting perspective.' ([n. 45] i 37.)

50 See section A; also the general treatments of the ceremony mentioned in $n$. 14 . 
has been $\alpha \pi \varepsilon ı$ ó $\delta$ akpus. ${ }^{51}$ In a passage of Sophokles' Trachiniai heavily influenced by the wedding song ${ }^{52}$ Deianeira expresses to the leader of the chorus of girls the hope that they will not suffer what marriage has brought her, vũv $\delta^{\prime}$ ỡmeıpos $\varepsilon \bar{l}$, and proceeds to illustrate the point by comparing the unmarried girl to a protected or untroubled young animal or blooming plant. This image seems to have been a tómos of the wedding song. For example, Sappho fr. I04(a), whatever precisely the original text, probably compares or contrasts the separation of the bride from her mother with the life of pastoral animals. Later in the Trachiniai Deianeira as a bride is

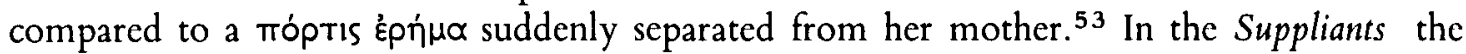

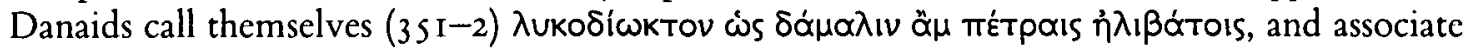
themselves with the sufferings of their ancestor, the móptis lo (4I), whom they twice call 'mother'. ${ }^{54}$ To the pastoral scene of her sufferings they regard themselves as having returned. ${ }^{55}$ Mention should perhaps also be made in this context of the image of the hawk preying on the nightingale (62) or dove (223-6; cf. PV 857). It is true that this image does not appear in the meagre remains of the ancient wedding-song; but it may be significant, in view of the demonstrable continuity of similar images in the wedding as well as of details of the ritual itself, 56 that the image of the bird of prey catching a weaker bird (e.g. the partridge) is a feature of the Greek wedding-song in the mediaeval and modern period. ${ }^{57}$

The grazing animal may have to face not only isolation and beasts of prey but also subjection

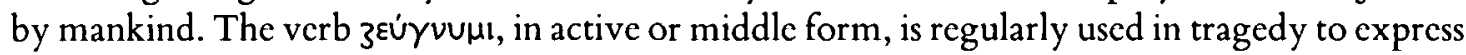
what a man does to a woman in marrying her. ${ }^{58}$ Zcus in giving Thetis as wife to Pelcus ávopi

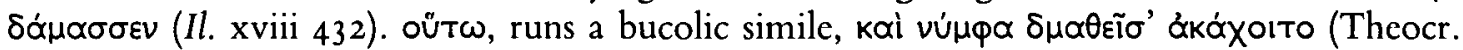
8.9I). The Danaids compare themselves to a $\delta \alpha \mu \alpha \lambda ı$ (see above), a word cognate with $\delta \alpha \mu \alpha \dot{z} \omega$ and applied to an animal (generally female) not yet tamed or subdued. At I 44- 53 they involve

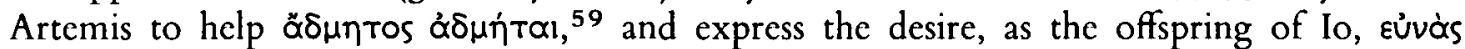

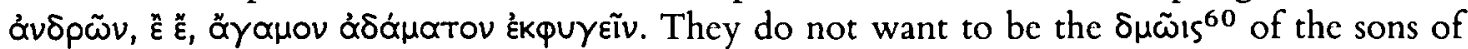

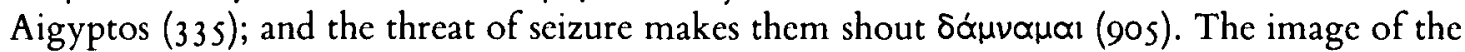
murderous Danaids as nanctae vitulos leaenae (Hor. C. iii I I.4I) expresses not only savagery but also the reversal of the hymenaial image of the heifer subdued.

When Deianeira praises the life of the unmarried girl, she alludes to the hymenaial imagery not only of the untroubled animal but also of the protected, flowering plant. ${ }^{61} \mathrm{We}$ find plant images used on the one hand to praise bride or groom, ${ }^{62}$ and on the other hand, like the animal imagery, to express the negative aspect of the loss of girlhood: in Sappho a hyacinth trodden

51 Su. 69-76; sec also e.g. $74^{8-9}$.

52 I 4 I-9; Seaford (n. 33.)

53 s29-30; if. also Lyk. Alex. I02; E. IA I083-8, Hel. I 476-8, Hek. 205-I0 ( $f .90-\mathrm{I}, 4$ I6-I 8, 526, 6I 2); Pi. Isthm. 8.48.

54 I 4 I, 539; ff. $5 \mathrm{I}, 275$ This appeal (I) expresses the Danaids' claim on the Argives; (2) may express, according to the psychoanalytic analysis of $\mathrm{R}$. $\mathrm{S}$. Caldwell (in Arethusa vii [1974] 45-70), their desire for a 'fantasised mother'; (3) is highly apt for their quasihymenaial position, particularly given the hymenaial Tómos of the heifer parted from her mother. $C f$. also $P V$ $665 \mathrm{ff}$.

$5540-56,538-40,1063-6$. Cf. PV 665 ff., where Io is forced out ( $\dot{\omega} \theta \varepsilon i v)$ of the parental home to become a heifer on the margins of the land. R. D. Murray, The motif of Io in Aeschylus' Suppliants (Princeton 1958), ignores the ritual dimension.

56 Seaford (n. 33) esp. nos. 10, I4, 20, 24; F.

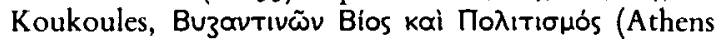
1948-1955) iv 88-92, 101-19, 148-85. Politis (n. 2.)

57 Politis (n. 2) iii 283; L. M. Danforth, The death rituals of rural Greece (Princeton 1982), I I4; E. Zakhos,
Poésie populaire des Grecs (Paris 1966), 66, 132; $f$. Alkman fr. 82.

${ }^{58}$ E. Ba. 468, Phoen. 337,1366, IA 698, Tro. 676, Alc. 994; cf. S. Trach. 536; E. El. 99, Hipp. 549, Su. 822; and esp. S. fr. 583 . Cf. Xen. Econ. 7. I I; A.R. 4.96; Suda and Hsch. s.v. 'juyóv'; Ps. D.H. Epid. 262; etc. (Magnien [n. 9) I $30-1$.)

${ }^{59} \mathrm{Cf}$. Timarete before her wedding dedicating her childish things to Artemis Limnatis, kópaı kópa, ஸ́s

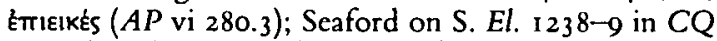
$\operatorname{xxxv}(1985), 321-2$. The Danaids' devotion to Artemis (cf. e.g. I03 I) is of course not an explanation of their hostility to marriage (as believed by some) but a consequence of it.

${ }^{60} \mathrm{~A}$ word associated with $\delta a \alpha \mu \alpha \mu \alpha ı$ (sec FJW ad loc.).

${ }^{61}$ See Easterling ad loc.; Seaford (n. 33).

62 E.g. Sappho fr. II 5 , and I $17 \mathrm{~A}$ (Lobel-Page Addenda); Theocr. I 8.30; Seaford (n. 33) 52 n. Io; add E. Hipp. 630, Med. 23 I (cf. 242); Greg. Naz. PG 37.1493

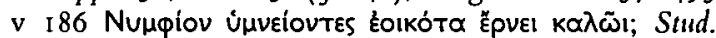
Bizant. iv (Rome 1935) 234 vs. $29-30$ and 235 v. 64. 


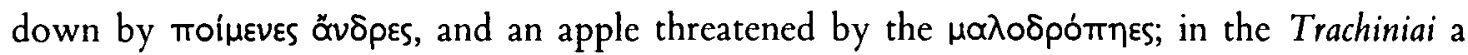

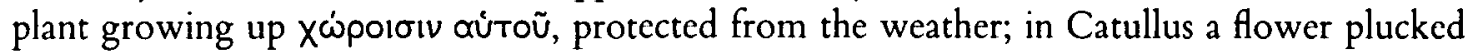
from a sheltered garden. ${ }^{63} \mathrm{We}$ should compare those cpitaphs such as the one from Leontopolis (first century $\mathrm{AD})^{\mathbf{6 4}}$ in which the girl, buried in her wedding attire, was about to leave her

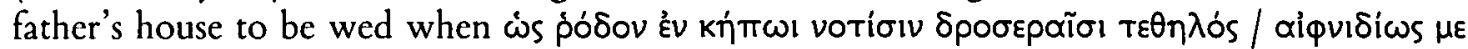

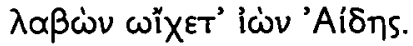

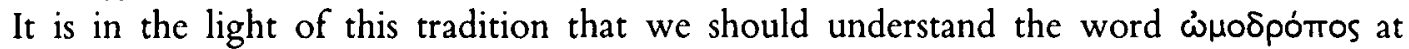
Acschylus Septem 333 (see below, $\complement_{1} 2$ ), as well as thrce passages from the Suppliants. Danaos, concerned with the possibility of male admiration in Argos, says of his daughters Tépeıv' ómépo

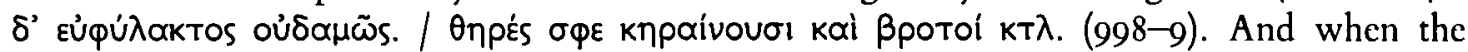

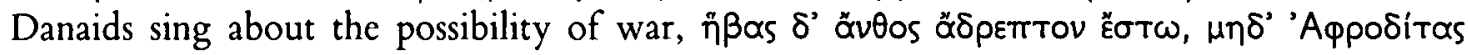

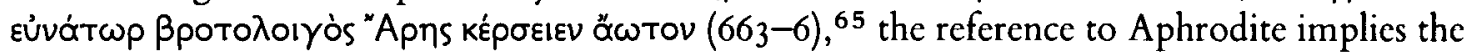
familiar idea that what warfare is for the young man marriage is for the girl, ${ }^{66}$ and therefore the hope in this case that the plucking of the bloom of youth can be avoided for both sexes.

About their prospective Egyptian bridegrooms, on the other hand, the Danaids sing ( $\mathrm{IO}_{4}-6$ )

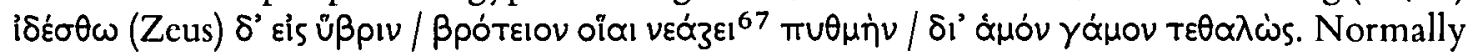
the bridegroom is praised by a comparison with a plant (see above, n. 62). But here the comparison has been reversed to express female disapproval. I suspect that this kind of reversal derives from the amoebean form exemplified by Catullus 62, in which the male chorus respond to the girls' complaints (cruel Hesperus, the bride as a plucked flower) by praising Hesperus and comparing the bride to a vine needing the support of an elm. I will return to this point below.

Many of the passages discussed, in the Suppliants and elsewhere, seem to impute brutality to the male. There are in fact scattered pieces of evidence for the expression of fear in the ceremony by the bride (see $n$. 3 above). Certain features of the fifth century BC Attic wedding ceremony

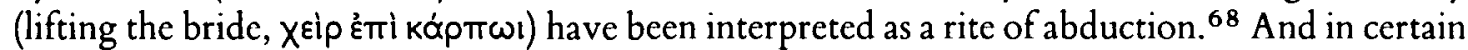
vasc-paintings (notably an Attic skyphos of $c .430 \mathrm{BC}$ ) the abduction of an obviously reluctant Persephone by Hades in his chariot resembles the wedding scenes in so many respects that it has been suggested ${ }^{69}$ that her reluctance reflects a real-life marriage ritual, in which the bride may be imagined as a departing soul. If so, this is further confirmation of our view that the wedding was associated with death, and further light on the ease with which the death of the unmarried girl is imagined as seizure by Hades as husband (see above).

The Danaids face abduction by the black ${ }^{70}$ Aegyptiads. They also describe themselves as lamenting, firstly in fear of being without $\phi i \lambda o r$ in Argos (69-76), and then again, following

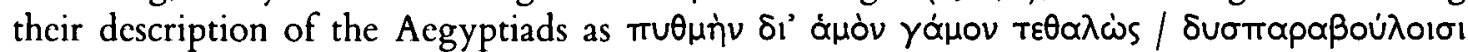

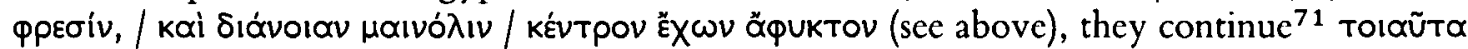

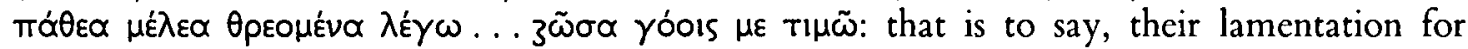
themselves as if already dead ${ }^{72}$ seems to emerge from consideration of the sexual aggressiveness of the Aegyptiads. Kévtpov ( 110 ) is an image of sexual desire, ambiguous here ${ }^{73}$ inasmuch as

${ }^{63}$ Sappho frr. Iosa, b; $c$. Himerius ix 16 (Colonna); S. Trach. I44-9; Catull. 62.39-47; cf. e.g. Politis (n. 2) iii $28 \mathrm{I}$.

${ }^{64}$ Peek (n. II) I238; ff. e.g. I162.8, I80I; Alexiou, (n. I2) 195 .

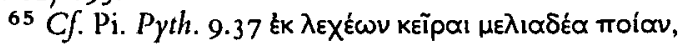

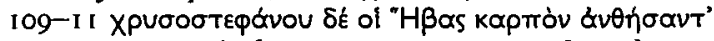

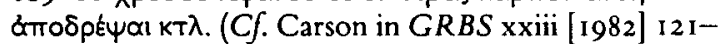
8).

${ }^{66} \mathrm{~J}$.-P. Vernant (n. 9) 23.

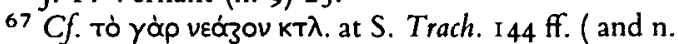
33 above).

${ }^{68}$ Jenkins and Sourvinou-Inwood (n. 3). It is interesting that at Iambl. Vit. Pyth. I 8.84 certain rituals to which the bride is subjected are explained by her position as suppliant.

${ }^{69}$ Jenkins (n. 3) I 42.

70 The emphasis $(719,745)$ on their blackness, as they approach intent on abduction, may connote death. If it is thought that this can be no more than a realistic detail, cf. the black Egyptian Zeus-Hades gaining access to Io in S. Inachos (Seaford in CQ xxx [1980] 23-9). And other references in $S u$. to black skin (of the Danaids) certainly connote death (154; Seaford, art. cit., 24; of. also 785 , $790-1,778)$.

71 104-10 and I I2-I6: I omit the very corrupt line III.

72 Cf. S. Ant. 80 s ff.; Seaford (n. 23) 254.

${ }^{73}$ As noted by FJW, who also suggest an allusion to Io. 
ẼX $\omega \nu$ can mean both 'feeling' and 'wiclding'. ợukTov with its connotation of death ${ }^{74}$ provides a

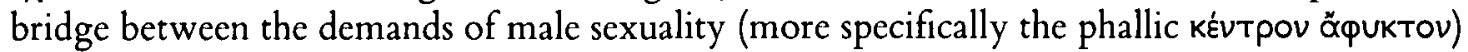
and lamentation. ${ }^{75}$ In addition, the association of death (particularly of a virgin) with marriagc sometimes extends to an assimilation of the destruction of the body to the first physical contact of the married pair. ${ }^{76}$ Accordingly, the Danaids' threat of suicide is presented as a preference not only for one husband (Hades) rather than another, but also for one kind of physical contact rather than another. For that seems to be the point of the corrupt lines 788-92 $\theta \dot{\varepsilon} \lambda$ ol $\mu 1 \delta^{\prime}$ ờ $v$

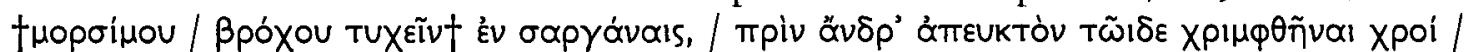

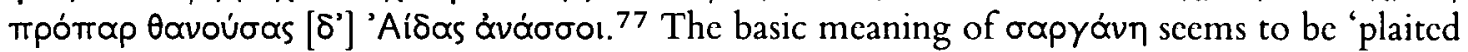
work' (FJW). And so its point here may be to assimilate the noose to something woven or plaited ${ }^{78}$ which would touch, surround or clasp the head or body of the bride (the crown? the

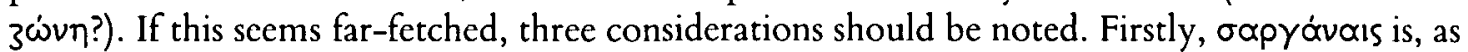
FJW argue, unlikely to be corrupt. ${ }^{79}$ Secondly, in a story told by Plutarch (Mor. 253d) a virgin

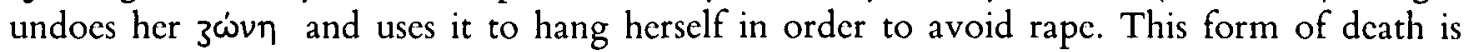
interpreted by Helen King ${ }^{80}$ as an inversion of marriage: the undoing of the girdle is associatcd with marriage, but hanging, unlike marriage, produces no bloodshed. Thirdly, there is a similar perversity in the stress laid on the fineness of the woven cloth in which Antigone is found hanged

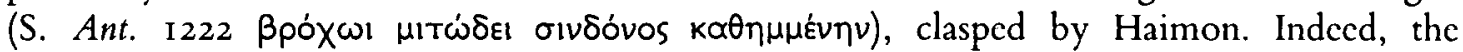
presentation of the death of Antigone as a wedding, both in her passage to the Tú $\mu \beta$ ßo- $-\nu \cup \mu \varphi \varepsilon i o v$ (89I) and in the messenger's narrative, is so pervasive that I believe that the attire in which she goes there, and with which she hangs herself, is bridal. Then as now in Greece, the unmarried might go to their tombs dressed for the wedding. ${ }^{81}$

The association between marriage for a girl and death, based as it is largely on a manifold resemblance (details of the ceremonies, abduction by a male, fear of the unknown, etc.), facilitates the association here of the sexual aggression of the suitors with self-lamentation and death. If the ancient Greek wedding also sometimes included elements of lamentation, this would bc onc of a large number of points of continuity with the modern Greck wedding. ${ }^{82}$ An (apparently Hellenistic) epitaph ${ }^{83}$ speaks of a girl who ncither came to the bridal chamber nor

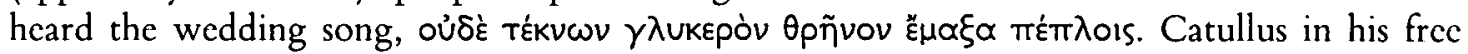
translation of Callimachus speaks of the falsae lacrimulae of brides, ubertim thalami quas intra limina

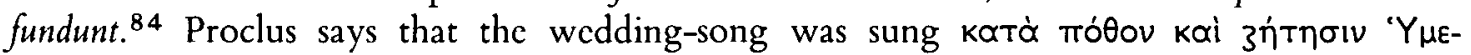

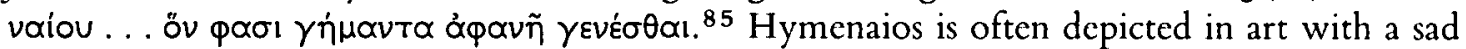
cxpression. ${ }^{86}$ And he has a habit of turning wedding celebrations into funcral lamentations. ${ }^{87}$ Pindar groups together three kinds of song for the ultimely deaths of, respectively, Linos,

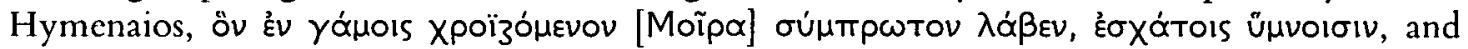

${ }^{74}$ Cf. c.g. Simon. 520 PMG 4; S. Ant. 36I-2; Peek (n. I I) 1039.7 , I $593 . \mathrm{I}$.

${ }^{75}$ Cf. Simon. (406-7 Page Epigr. Gr.) oủk $z \pi m i \delta \omega \nu$

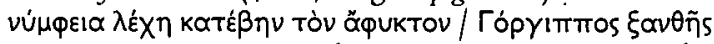

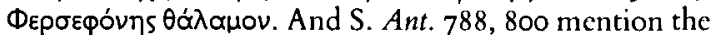
inescapability of "Epws in a context which combines the themes of marriage and death ( $f$. e.g. 804 tòv

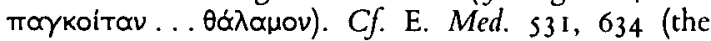
ǻukтos arrows of love); also perhaps A. Su. 784 .

${ }^{76}$ Cf. E. Su. Ior9-30, Hcld. 913-5, Cyc. sis; Pi. fr. 1 39.6 ; cf. S. Trach. 662 (cf. 833, 857-8, ctc.); E. Hec. $366-$ 8. Cf. also below on S. OT, Trach, Ant., and A. $A g$. (\$6).

77 The text as printed by FJW. With dudaool they compare 906 ăvaktas meaning husbands. Cf. also 804-S (with koira cf. c.g. S. Ant. 804, OC I 706; A. Ag. 1494).

${ }^{78} \mathrm{Cf}$. $\pi \lambda \varepsilon \mathrm{kT} \alpha \tilde{\mathrm{I}} \mathrm{S}$ at S. OT ${ }_{\mathrm{I}} 264$ and $\mu \mathrm{TT \omega} \delta \varepsilon \mathrm{at}$ S. Ant. 1222 (sce bclow).

79 In fact the only plausible replacement I can think of is the slight change zapyóvars (occurs elsewhere only in Schol. Opp. H. i Ioo meaning taivia), which would in fact suit my argument somewhat better. Өaveĩ for TUXeiv in 789 would remove all the problems noted by FJW, but the corruption would be hard to account for. 80 Images of women in antiquity (London and Canberra 1983; edd. Averil Cameron and Amelie Kuhrt) i $18-21$. Scc now also Nicolc Loraux, Façons tragiques de tuer wne femme (Paris 1985) 34-5, 4I-5, I05 n. I s.

81 Peek (n. II) 1238.3; E. Tro. 1218 ff.

82 Sec e.g. Politis (n. 2) iii. 278-9; Danforth (n. 51) 74-9; Alexiou (n. I 2) 1 20-2.

${ }^{83}$ Pcck (n. I I) 947: from the second or first century BC, provenance unstated.

84 Catull. 66.16-7; ff. also 61.181 flet quod ire necesse est; etc. (nn. 2 and 3 above).

${ }^{85}$ Chrest. ap. Phot. Bibl. 239 (p. 321.30 Bckker); of. also Tzetzes Chil. xiii 606 (the wedding-song sung by

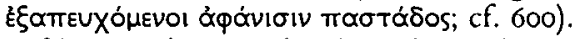

86 Daremberg-Saglio (n. I4) s.v. 'Hymenaios', p. 335.

87 Alcxiou-Dronkc (n. 12) 830-7; ff. n. 20 above. 
lalemos. ${ }^{88}$ It has been argued that this means that Pindar regarded these three kinds of song as various forms of the $\theta$ p ñvos. ${ }^{89}$ In a comparable focusing of the negative cmotions of the wedding onto a mythical figure, the girls of Trozen cut their hair before their weddings (in mourning) and shed tears for Hippolytus. ${ }^{90}$

The Danaids return to the association of the proposed marriage with death in the song that

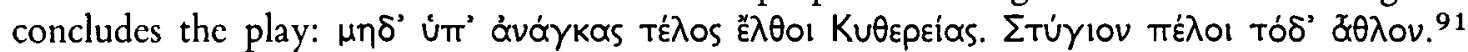
Marriage and death are both $\tau \dot{\tau} \hat{\lambda} \eta{ }^{92}$ The Danaids desire the $\tau \dot{\varepsilon} \lambda$ os of this marriage (if inevitable) to be the té $\lambda$ os of death.

This final song, it is gencrally agreed, is divided between two parties. FJW have recently produced a very powerful case for assigning the other part to a chorus consisting not, as often belicved, of the Danaids' maids, but of the Argive bodyguards. I would like to add the suggestion that the song is influenced by, and would evoke in the minds of the audience, the wedding song. The only surviving wedding song that consists of a dialogue between a male and a female chorus is the very Greck Catullus 62. But there are suggestions of the practice in the fragments of Sappho. ${ }^{93}$ And in one of the two surviving fragments of the Danaid trilogy itself there is mention of kópol and kópal singing the song sung on the morning after the wedding night (see below).

In Catullus 62 the young men take up and reverse the themes of the girls' complaints (cruel Hesperus, the bride as a plucked flower), and thereby attempt to persuade them and the bride of the desirability of marriage (Hesperus is praised, the girl is like a vine necding support). Persuasion (Pcitho) was according to Plutarch one of the deities needed by oi yauoũvtes, the others being Zeus Teleios, Hera Teleia, Aphrodite, and Artemis. ${ }^{94}$

Turning to the final song of the Suppliants we find that Zeus, Hera, Aphrodite, Artemis, and Peitho are in fact all mentioned within lines r030-4I, along with Pothos and Harmonia. The Danaids have praised the fertility of Argos and then appealed to Artemis and rejected the TÉ $\lambda$ os

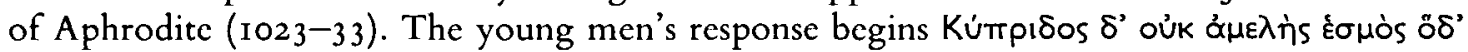

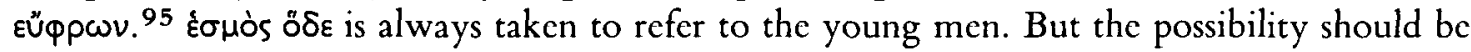
considered of at least a secondary reference to the Danaids. At 223 the Danaids are called $\dot{\sigma} \sigma$ uò ஸ́s $\pi \varepsilon \lambda \varepsilon 1 \alpha \dot{\delta} \delta \omega \nu$. The young men may be almost playfully picking up the praise of fertility (see esp. I028 то $\lambda$ Útekvol) as an indication of the girls' interest in Aphrodite despite their cxplicit rejection at $\mathrm{IO}_{3} \mathrm{I}-2$. This interpretation coheres well with the association by A phroditc herself of the fertility of nature with marriage later in the trilogy (probably indeed in the act of persuading the Danaids of the desirability of a marriage: see below). And with the almost playful spirit $c f$. Catullus 62.43 , where the young men say of the girls' complaints quid tum si carpunt tacita quem mente requirunt?

The Argive soldiers then go on to praise A phrodite and associate her with the other deities of marriage (see above). They also respond to the Danaids' association of the Té $\lambda$ os of marriage with death by obscrving, in the corresponding place in the verse, ${ }^{96}$ that the $T \varepsilon \lambda \varepsilon u \operatorname{rad}^{97}$ of

${ }^{88}$ Fr. I $28 \mathrm{c}$ Snell; with xpoïzónevov of. n. 76 above.

${ }^{89} \mathrm{M}$. Cannatà Fera in GIFC xi (1980) $18 \mathrm{I}-8 ; c f$. Alexiou (n. 12) $57-8$.

90 E. Hipp. I425-9; Pausan. ii 32.1 ; 'Die Tränen, die sie ihm weinten, flossen zugleich um Jenen Teil des eigenen Ich, der mit dieser Geste und an diesem Tage für immer ging' (W. Fauth, Hippolytus und Phaidra, Abh. Ak. Wiss. viii [Mainz 1959] pp. 392-3); $f$. Wilamowitz, Euripides Hippolytus, 27; Séchan in REG xxiv (19I I), IIs ff.; on the hair see Fauth $389-93$.

91 1032-3; for text and interpretation see FJW ad loc. $I$ discuss this song in more detail in the most recent issuc of Dioniso (in Italian).

92 This point is made explicit by Artemidorus Oneir. ii 49; $c$. also U. Fischer, Der Telosgedanke in den Dramen des Aischylos (Hildesheim 1965), 52, 56-57.
93 Frr. 27.10, 30.6-7, 43.8-9 L-P; A. P. Burnett, Three archaic poets (London I983), 2 18; sce also Sencca Med. ro8; Himerius Or. ix 21; Procl. Chrest. ap. Phot. Bibl. 239, p. 32 I Bekker. There are choirs of youths and maidens in the wedding procession in the Hesiodic Aspis $(276-84)$.

${ }^{94}$ Mor. 264 b; cf. also D.S. 5.73.24; Schol. Ar. Thesm. 973; Peitho and marriage: refs. in R. G. A. Buxton, Persuasion in Greek tragedy (Cambridge 1982) 35 (add Pi. Pyth. 9.39; Himer. Or. ix, 19); Sourvinou-Inwood, below p. 145 f.

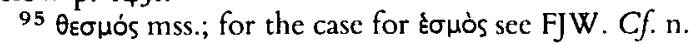
106 .

$96 \operatorname{IOS} \mathrm{I}-2$; and note $\mathrm{IO} 33 \pi \dot{\varepsilon} \lambda \mathrm{OI}=\mathrm{IOS} \mathrm{I} \pi \hat{\varepsilon} \lambda \epsilon \mathrm{l}$.

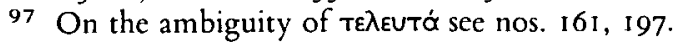


marriage has happened to many women in the past. The Danaids respond by invoking Zeus on

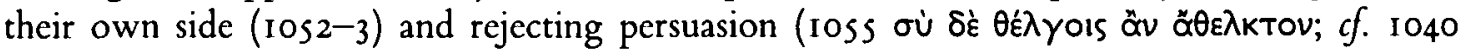
$\theta \dot{\varepsilon} \lambda$ кторı $\left.\Pi_{\varepsilon} \theta 0 \tilde{\imath}\right)$. Still, the girls do then admit that the mind of Zeus, which for the young men is associated with marriage, is obscure (1057-8), and the manner of their second appeal to Zeus to

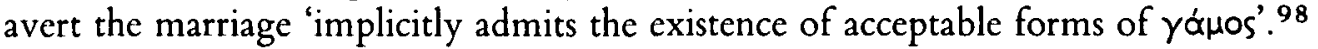

As in Catullus 62, the male chorus picks up and reverses what has been said by the female. But whereas in Catullus, as in a normal marriage, the male persuasion is imagined to be successful, in Aeschylus it is at best partially so, as we see more clearly of course in the sequel. The only Danaid to spare her husband is Hypermestra, who then, according to Pausanias (ii 2I.I), dedicated a temple of Artemis Peitho in Argos. The Suppliants ends on a note of anxiety ${ }^{99}$ comparable to the ending of Agamemnon or Choephoroi, except that here the anxiety is enriched by the subtle evocation of a familiar process which would normally, outside the theatre, end with the acquiescence and incorporation of the bride.

To the other two plays of the trilogy there are only two fragments which can be confidently assigned. One of them (43Radt) is transmitted as follows

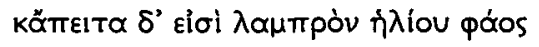

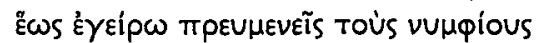

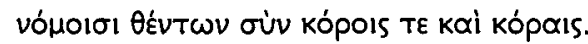

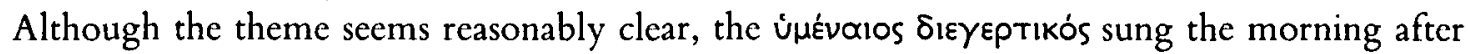

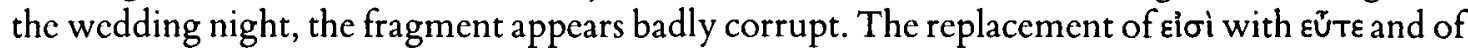

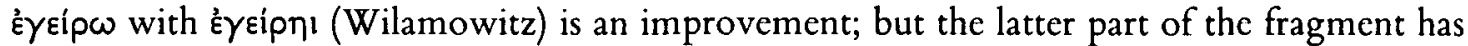

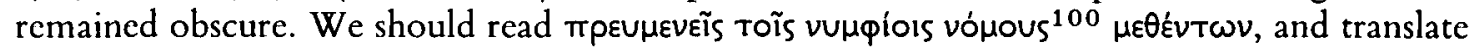
'and then when dawn arouses the radiant light of the sun, let them sing with the youths and girls songs to propitiate the bridegrooms'. Compare e.g. A. Pers. 609 matpi (i.e. the dead Darius)

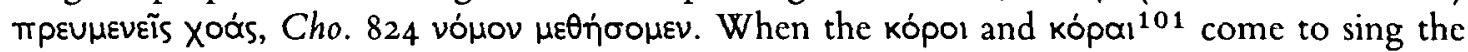
$\delta$ ¿eүeptikov, the bridegrooms will be dead, murdered by the brides, rather as in Euripides the girls come to sing a wedding song for the dead Phaethon which, because he has in fact just been killed, is soon followed by a lament. ${ }^{102}$ What is envisaged (by Danaos?) in this fragment is that the brides are to sing a song to propitiate ${ }^{103}$ the husbands they have murdered. Whether this is

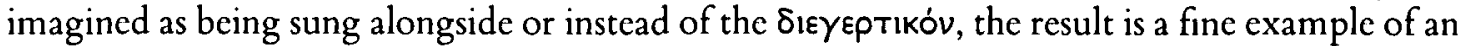
idea to which tragedy constantly returns: the often horrific contrast between songs opposed in mood. ${ }^{104}$

We do not know, of course, how the trilogy ended. One suggestion is that the confirmation of the institution of marriage was accompanied, perhaps as a means of reconciling women to marriage, by the foundation of a festival conducted by married women in the interests of fertility, the Thesmophoria. It has been pointed out that according to Herodotus the $\tau \varepsilon \lambda \varepsilon т r$ ' called $\theta$ eoroqópia by the Greeks was brought from Egypt by the Danaids, and that the Danaids

98 FJW ad I062-7. I adopt their distribution of the lines in this passage, which is in essentials certainly correct.

${ }^{99} \mathrm{~A}$ comparable point is made about the metre of the cxodos by J. N. Rash, Meter and language in the lyrics of Aeschylus' Suppliants (New York 198I), 194, I99: '... the [thematic] clash is summarised a final time in metrical form... The decisive "victory" of the Danaids' attitude is reflected ... by the appearance of the lekythion which represents suicide, death, and murder to come...'

100 Onc ms. (B) has vónols (rather than vónoırı).

101 Interpretation of the $f r$. has been hindered in part by the mistaken view, derived from the scholiast on Pindar (Pyth. 3.27) who quotes the passage, and Hsch. ii

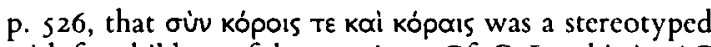
wish for children of the marriage. Cf. G. Lambia in $A C$ s5 (1986), 66-85, which appeared too late for consideration here.

102 E. Phaeth. $227-44,270$ ff.; cf. IT 365-8, Tro. $35 \mathrm{I}-2$; S. fr. 725; Alexiou-Dronke (n. 12) 833, 835 .

103 Propitiation was a function even of the normal lament: Alexiou (n. 12) 55, I82.

104 E.g. A. Ag. 707-I I, Cho. 342-3, Sept. 868-70, 9I5-2 I, Pers. 605; S. Phil. 212-19, fr. 86I; E. Alc. 760

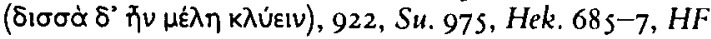
$75 \mathrm{I}-2, I T 185,22 \mathrm{I}-5,365-8$, Tro. $121,148-52,336$ (cf. $35 \mathrm{I}-2) ; f r$. I $22 ;$ Tr.fr. adesp. 663.16-I 8; cf. e.g. Ov. Her. 12.139-40; $A P$ vii 711. The contrast is particularly cffective if the songs also have elements in common. 
are independently associated with the watering of the Argolid. ${ }^{105}$ One further connection remains to be suggested. On the one hand the Thesmophoria is a festival in which, as in Aphrodite's speech in the Danaid trilogy (see below), agricultural fertility is associated with the fertility of women. ${ }^{106}$ But on the other hand the festival is characterised by an 'emphatic antisexual ethos' (abstinence, violence against male intruders), ${ }^{107}$ which can be seen as the negative side of its function as a fertility rite, ${ }^{108}$ and which may perhaps have been associated with the ethos and behaviour of the Danaids, particularly if they were eventually reconciled to marriage by Aphrodite's linking of marriage with the agricultural fertility produced by the union of heaven and earth (see below).

This is of course speculative. But if there is any truth in it, it would exemplify a phenomenon found elsewhere in tragedy: the pitiable events of the play provide the aition for the negative tendency of a ritual. The most obvious example is from the Hippolytus: girls before their marriage will henceforth lament, for Hippolytus (see above). Less obvious is the Bacchae: the sufferings of Pentheus represent in an extreme form the sufferings of the initiand into the Dionysiac mysteries, which are founded at the end of the play. ${ }^{109}$ As for Aeschylus, the only genuine extant ending of a trilogy, in the Eumenides, is in this respect barely comparable: the cult of the Eumenides is founded in Athens. But it does provide a parallel to reconciliation of the defeated party by $\pi \varepsilon \mid \theta \omega$ and to the resolution of conflict in the foundation of a cult associated with the fertility of the land. On the other hand, a major objection to this view is that no evidence survives for a substantial connection between the Thesmophoria and marriage. ${ }^{110} \mathrm{I}$ would like therefore to make another suggestion.

Hyginus (273) mentions games at Argos founded by Danaos filiarum nuptiis cantu, unde hymenaeus dictus. ${ }^{11}$ Much in Hyginus derives from the tragedy. ${ }^{112}$ If the trilogy concluded with the institution of the wedding-song, perhaps in the context of a remarriage of the Danaids, this would be a good example of the kind of tragic aition just described. In the trilogy pitiable events and female reluctance and lamentation are expressed in songs which resemble formal wedding-songs. The antithetical character of these songs, which arises naturally out of the story, may, in the context of the successful hymenaial transition at the end of the trilogy and the foundation of the formal wedding-song, have been adduced to explain the antithetical character of the formal wedding song.

The case for supposing that the remarriage (with Greeks this time) was represented, or at least prepared for, at the end of the trilogy is much stronger than is realised by those who support it. ${ }^{113}$ This is because a remarriage provides such an excellent context for the only other fragment that certainly belongs to the trilogy ( $44 \mathrm{Radt})$, in which Aphrodite describes the action of "epws in uniting heaven and earth and thereby producing the fertility that benefits mankind. She

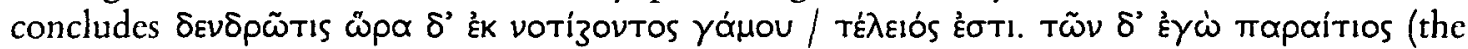
textual problem does not affect my point). This time, as opposed to the ending of the first play of the trilogy, the persuasion, uttered by the goddess herself, is successful. The presence of

${ }^{105} \mathrm{Hdt}$. ii I 7I; Hes. fr. $128 \mathrm{M}-\mathrm{W}$; D. S. Robertson in CR xxxviii (I924) $5 \mathrm{I}-3$; Thomson (n. 46) ch. I6. The Thesmophoria was apparently first suggested in 1838 by A. Tittler (Garvie [n. 45] 227).

106 See e.g. Nilsson, Geschichte der Griechischen Religion $^{3} \mathrm{i}_{465}$. It is interesting in this connection to

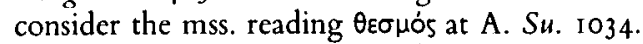

107 R. Parker, Miasma (Oxford 1983) 8I; W. Burkert, Greek religion (translation, Oxford 1985) 244; Detienne (n. 9) 78-81.

108 'The ritual focusses attention on the idea of productive sexual union by a paradoxical temporary insistence on its opposite' (Parker [n. 107] 83).

109 Seaford in CQ xxxi (I98I); cf. also E. Med. I 382 with A. Brelich, Paides e Parthenoi (Rome 1969); and IT 1454, I 459 with Brelich 242 ff.
110 Although of. Robertson (n. IO5) 53, who cites Call. Hymn Dem. I9; V. Aen. iv 58; Calvus ap. Serv. ad Aen. iv 58; Plut. Mor. I 38b. Cf. Od. xxiii 296. And the participants in the Thesm. are (mainly or) entirely married women: Parker (n. 107) 83; Detienne (n. 9) 7682; Burkert (n. 107) 242.

${ }^{11}$ Cf. Pi. Pyth. 9, where the Danaids' (second) husbands are chosen by an athletic contest (also in Pausan. iii 1 2.2; A poll. Bibl. ii I.5). The disappearance of Hymenaios on his wedding night is associated with Argos at Tzetz. Chil. xiii 599; schol. Il. xviii 493; etc. (Roscher, Lex. Myth i 280I).

112 E.g. for a detail of Aeschylus' Lykourgos trilogy preserved only in Hyginus see D. F. Sutton in RSC xxiii (1975) 356-60.

113 Listed by Garvie (n. 45) 226. 
Aphrodite even at the ordinary weddings of mortals is imagined by, among many others, Sappho, and in the tómol prescribed by Menander Rhetor; ${ }^{114}$ her characteristic role is to persuade the bride or to bring her to the groom. ${ }^{115} \mathrm{We}$ sometimes find Aphrodite depicted with the bride in classical Attic vase-painting. ${ }^{116}$ And the role of sexual union in the cosmos and in nature, for example in the union of heaven and earth, was a tómos at least of the later wedding ceremony. ${ }^{117}$

We may now return to the problem of the motivation of the Danaids, which can be seen in a new light. Given that their attitude and actions exemplify that apparently fascinating disruptive victory of the negative over the positive tendency in marital ritual that is a general feature of tragedy, the theme of endogamy is particularly well chosen as an agent of the disruption. It is not that a man claiming a bride under the law of the heiress might do so with a special degree of sclfish and dominating urgency, conceivable though this is. More important is the motivation made explicit in $335-9$ :

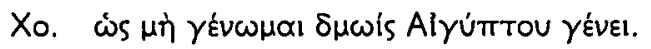

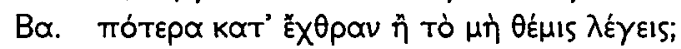

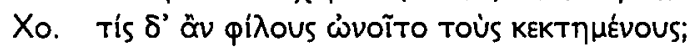

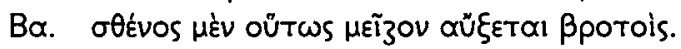

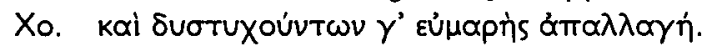

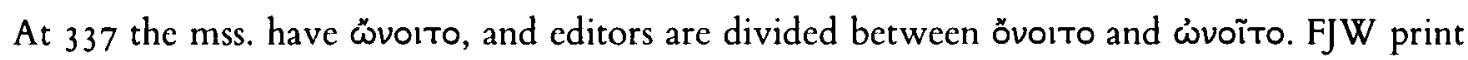

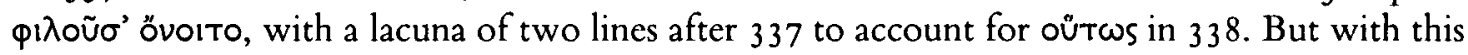

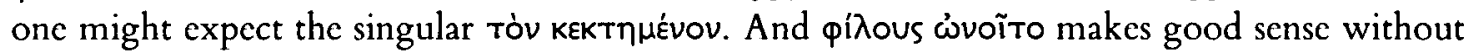
the need for a lacuna: 'who would buy (cf. e.g. E. Med. 232-4) фi ino as masters?', implying (in response to 336) paradoxical ẼX $\theta$ pa against $\varphi$ ì $\lambda$ o, 'kin', who would normally also be 'dear'. 118 Now whatever the truth of this much disputed problem, it is undisputed that 338 is an argument in favour of the marriage. But if so, then the Danaids' reply (339) must express agreement with and development of Pelasgus' observation; ${ }^{119}$ and so it cannot refer, as Garvic would have it, simply to the ease with which Pelasgus can abandon the Danaids. ${ }^{120}$ The $\alpha \pi \alpha \lambda \lambda \alpha \gamma \dot{\eta}$ must rather be a feature of the marriage, clearly divorce. ${ }^{121}$ The objection that 'divorce would be the very thing that the Danaids would presumably want' ${ }^{122}$ has no weight, for it is perfectly consistent for a woman to point to the ease with which she may be abandoned (and thereby perhaps isolated and disgraced) as one of a number of objections to entering on a marriage, particularly if

114 Sappho fr. I94 Voigt (Himer ix 4); Men. Rhet. 4I 2.12 Eíkòs tapeĩval . . , 407.7 (cf. 404.19-25, 406. I924); Dracontius 6; etc. (Reitzenstein in Hermes $x \times x v$ [1900] 97-9).

115 e.g. Men. Rhet. 407.7; Claudian x 2\$I-85; Stat. Silv. i 2; etc. (Reitzenstein [n. 14] 97-9); cf. E. Hipp. 553 (at the 'wedding' of Herakles and lole) 'A

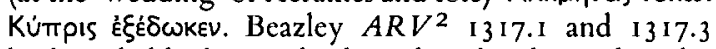
both probably depict a bride with Aphrodite and Peitho (cf. also e.g. 1325.27, 1 328.99). Cf. E. Hel. I 120-1 (quoted n. 19I below).

116 E.g. Bcazlcy, $A R V^{2} 1126.6$, I 33.196.

117 Men. Rhet. 401, 408.13-19; Ps. D.H. Epid. 262; Himerius ix 8; etc. (Reitzenstein $|n .114| 97-9$ ). If it dates back to the fifth century, then Aphrodite's speech might even have becn presented as an aition for it. Cf. $\delta 1$ (Antigone); Procl. Tim. iii $176.19-30$ Dichl ồ $\delta \dot{n}$ (Heaven-Earth union the first $\gamma \alpha \dot{\alpha} \mu s$, etc.) kai oi $\theta \varepsilon \sigma \mu o i$

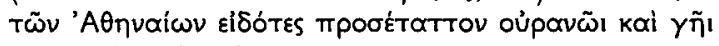

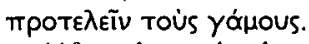

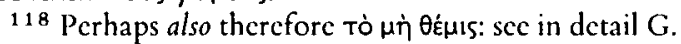
Thomson in Eirene ix (1971), 25-30 and (n. 46) 302-6, 450. There is no substance in the objection of FJW that "qixous can hardly mean "relation", as the idea of intermarriage is not alluded to until $387 \mathrm{ff}$ '. (it is mentioned there by Pelasgus!). They also object to ஸ่voĩto by comparing 202; but the Danaids need not have been penniless in Egypt. övoua does not seem to occur elsewhere in Attic (though of. v. Io).

119 Denniston, The Greek particles ${ }^{2}$ 1 57-8; kaí . . . үध is found in the play also at $296,313,468$.

120 (n. 45) 220; similarly FJW ad loc., who find an implausible link with 338 in the idea of male domination, which both gives the husband power and allows Pelasgus to abandon the Danaids casily! FJW also object

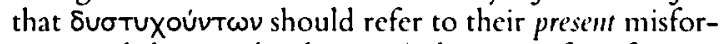
tunc, and that it is hard to sec "what sort of misfortune they can envisage as inducing their cousins to dissolve the union'. But the point is that the Danaids seem to cnvisage their present misfortunc, isolation and hostility as continuing into the marriage.

121 So Tucker, Headlam, Thomson, etc.; cf. Page on E. Med. 236 , Stevens on E. Andr. 529.

122 Garvic (n. 45) 220; similarly FJW ad loc.; this pscudo-problem prompts J. K. Mackinnon (CQ lxxi [1978] 78) to take the line as an indignant question implying that divorce is not casy. 
it is a specific response to the specific point made by Pelasgus. Another objection, that the Danaids' murder of their husbands is even more disreputable than divorce, ${ }^{123}$ is equally irrelevant, as it ignores the Danaids' various possible motives for the murder, c.g. resistance to defloration, revenge, certain and immediate freedom from the Aegyptiads. If 338 refers to the accumulation of property within the household by kinship marriage, ${ }^{124}$ then it coheres very well with our reading not only of 337 but also of 339 . For a girl who marries one of her father's kinsmen will of course encounter loyalty between them and her husband. She will be without separate kinsmen of her own to support her in a conflict. ${ }^{125}$ Hence perhaps the particular aptness

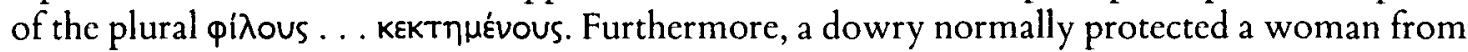
easy divorce, because it had in Attic law to be returned, in the event of a divorce, to her former kyrios. ${ }^{126}$ However, 'the epikleros had no such leverage; she could not take her fortune and return to her former kyrios, for it was to him that she was married'.127 She was therefore in an cxposed position. 'The epikleros was in a sense an heiress, in that the estate always passed to the oikos of which she was a member; but the property was her husband's, and the only check upon her husband's ability to spend it was the danger of a lawsuit when her children came of age and took it over.' ${ }^{28}$ Vulnerable in these and various other ways, the epikleros was in fact put under the protection of the archon. ${ }^{129}$ But of course this civilised protection by the Attic state was not imagined as available to the Danaids. Indeed, the Danaids, not unlike Orestes in the Oresteia, represent the kind of problematic case which required, historically, the intervention of the state in an area originally regulated by the kin.

What this problematic case means for the Danaids is an enhanced degree of the isolation and subjugation associated even with the unproblematic marriage. The normal bride in moving from one household to another is resentful, but she nevertheless preserves with the family she has left links which will re-emerge to support her in the event of divorce or conflict with her husband or his family. ${ }^{130}$ But the epikleros cannot look to any such support (and her mother's kinsmen do not of course even belong to her former olkos). To put it another way, the epikleros does in a sense fail, in her marriage, to make the marital transition to another family; she remains

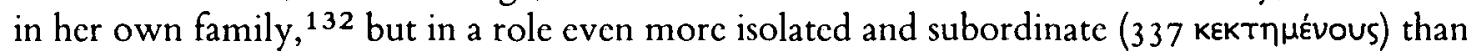
that of the normal bride in her new family.

This does not mean that the play is about the problems of the érrik $\lambda$ npos. There is, for example, no mention (except perhaps at 979) of an inheritance to be transmitted by the Danaids. The vulnerable isolation of women married to their agnatic cousins is alluded to only at $335-9$. This anomaly does however play a subtle role in the victory of the negative tendency in the marriage ritual. In the other examples discussed in this article, the victory is effected by a factor external to the marriage itself (another woman, Creon's edict, etc.). In the Suppliants on the other hand, as in the normal wedding, the negative tendency derives entirely from the bridal

123 Mackinnon (n. 122) 77.

124 Thomson (n. I I 8) 29, compares Pi. Isthm. 3.2 and E. El. 427

125 Thomson (n. I18) 29 cites Plut. Mor. $289 \mathrm{e}$ (the Romans, unlike the Greeks, prohibit such marriages) $\eta$,

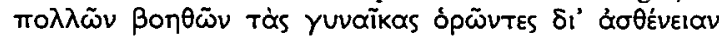

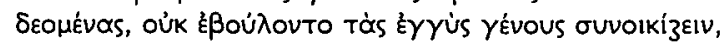

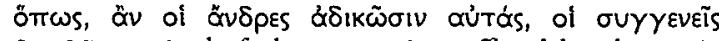

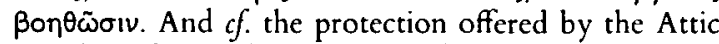

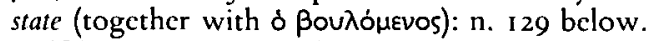

126 Sce c.g. D. M. Schaps, Economic rights of women in ancient Greece (Edinburgh 1979), 76. Add Isaeus iii 28, o Eyrúwv would have wanted a receipt for the dowry iva

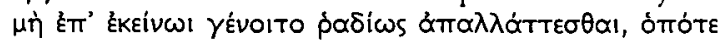

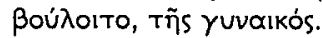

127 Schaps (n. 126) 26.

128 Schaps, (n. 126) 57; cf. 27-8.

129 Schaps (n. 126) 38 ; he notes that the archon has power over all possible abuses to which epikleroi were subject. Cf. also Ar. Ath. Pol. 56.6; Suda, Harpokr. s.v.

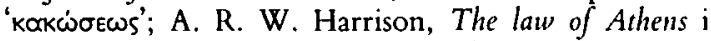
(Oxford I97I) 43. It was made easy for ó Bou $\lambda$ ó $\mu$ Evos to

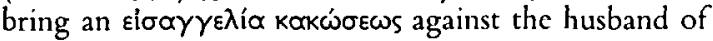
an epikleros.

${ }^{130} \mathrm{Cf}$. the loyalties of the wife reverting to her old household in myth (Althaia, Psyche, Eriphyle).

${ }^{131}$ It is interesting in this connection that no mention is made in the play of Danaids' mother(s); although they do claim kinship with the Argives through their ancestress Io, whom they call 'mothcr' (I5-18, 5I, I4I, 533, 539). They also appeal more than once to their immortal ancestor (on the maternal side) Zeus, who is however associated with marriage: note their quandary at 1057 ( $c f .40 \mathrm{ff} ., 1035,1051,1062-7)$.

${ }^{132}$ On this point see esp. J.-P. Vernant, Myth and thought among the Greeks (London 1983) 143-6. 
perception of the groom and of the transition. ${ }^{133}$ But how then in the Suppliants can the negative tendency credibly prevail? Largely because the Danaids and their cousins are exotic scmi-barbarians in a mythical era. By itself, however, this exotic factor is no more than a simple reversal in fantasy of Greek norms. ${ }^{134}$ Whereas the endogamous isolation of the woman, with which it is combined, is both familiar to the Greeks and ideally suited to heighten the fears and reluctance of the bride.

\section{The Death of The W}

15. Deianeira. The anxiety of the bride at isolation and loss of the bloom of youth (nos $\mathrm{I}^{-}-3$ above) is expressed also in Sophokles' Trachiniai ( $14 \mathrm{I}-9)$. Deianeira's negative emotions at her marriage persist into her married life, ${ }^{135}$ firstly because of her husband's absence on his labours, but then through her own fatal mistake, with the result that finally she complains that she is

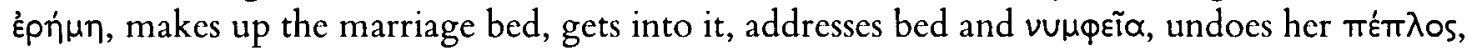

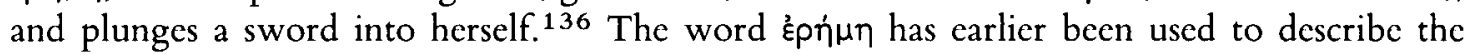
position of Deianeira as a bride, isolated from her kin but not yet incorporated into her new

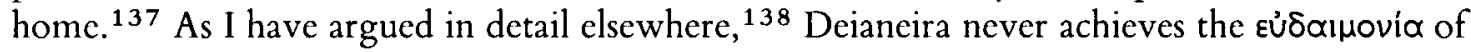
incorporation. The negative tendency in the rite of passage has emerged as a reality, the actual isolated death of Deianeira.

\$6. Eủరaınovia is also denied, of course, to Oedipus and Jokasta. There is a sense in which their marriage only appeared to be properly completed. Teiresias predicts to Oedipus (S. OT 420-3):

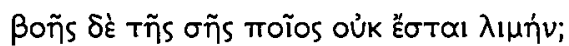

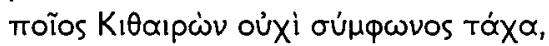

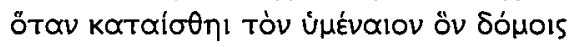

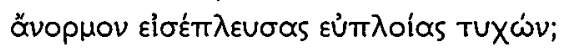

Dawe prints a lacuna after 422 . This is unnecessary. The cllipse would be acceptable given the familiarity of the processional wedding-song and perhaps also of nautical imagery surrounding the wedding procession. ${ }^{139}$ Familiar too is the idea that the joyful wedding-song will bc replaced by the cry of suffering, ßon, a word which can also refer to songs of joy (E. El. 879; Pi.

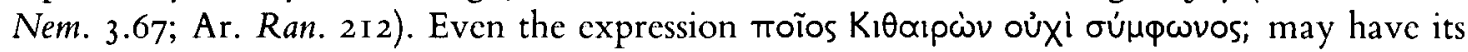
cquivalent in what is sung or said at the wedding. ${ }^{\mathbf{1 4 0}}$ And when the truth is revealed, Jokasta,

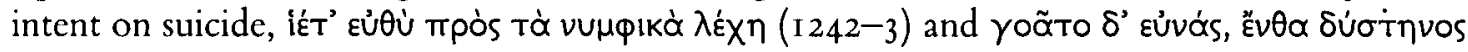

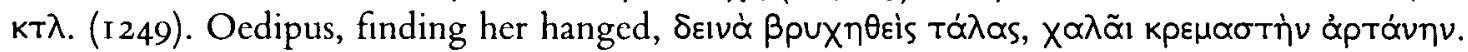

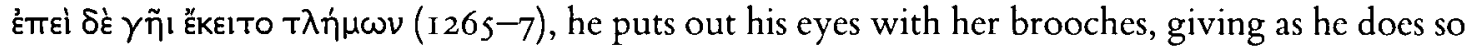
his reasons. The narrative continues:

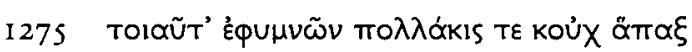

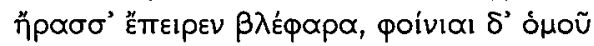

133 In this respect the remark of FJW (40) that the play is the earliest known text in European civilisation to have dealt with the problem of the arranged marriage is misleading to the extent that it ranges the Danaids along with the bride forced to marry someone she does not love, usually to the exclusion of the man she does love. Such a bride has feelings opposite to what we imagine to be the normal bridal ones of joy, love for her groom, affection for her parents; whereas the feelings of the Danaids are an intensification of normal bridal ones (attachment to father, resentment, fear of isolation and of male domination, etc.). Hence, incidentally, the problem of Danaos, who though sympathetic to his daughters neither asserts his paternal rights nor even expresses great hostility to the marriage (see FJW $35^{-6}$, who offer a different solution): he is in these respects just like the father of a normal bride. Cf. SourvinouInwood, below p. I 43 f.

134 Cf. e.g. the Amazons. Even the Lemnian women require an external stimulus (as of course does Lysistrata).

135 Esp. őkvos, uncertainty: 7,$181 ;$ ff. 37.

136 904-31; Seaford (n. 33).

137 s30; cf. S. Ant. 887; E. Andr. 854-5, Tro. 563-5,

$I A$ i 3 I 4; John Chrys. PG lxii 386.

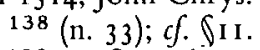

139 See $\oint 9 a$. The rare word $\varepsilon \dot{\pi} \pi \lambda$ oía occurs also at $A$. Su. 1045, again in the context of a disastrous marriage. 140 Ps. D.H Epid. 27 I (Rademacher); Men. Rhet. 399.29, 404.I7; Catull. 64.35-42; Hes. Aspis 284-5; Xen. HG iv I.9; D.S. xiii 84. I-3 (Tim. FGrH $566 \mathrm{~F}_{26}$ ); Sappho fr. $44 \mathrm{~V}$ I $3-14$. 


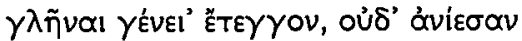

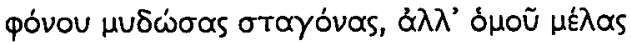

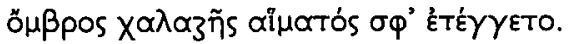

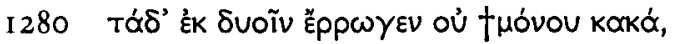

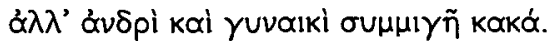

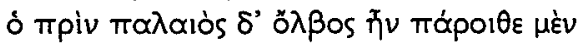

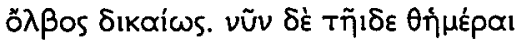 \\ $\sigma т \varepsilon \nu \alpha \gamma \mu o ́ s, k T \lambda$.
}

غ́ $\cup \mu \nu \tilde{\omega} \nu$ (I275) imparts a suggestion of ritual song, thereby reminding us of Teiresias' prophecy at $420 .{ }^{141}$ And there runs through the narrative the suggestion of sexual union, of a re-

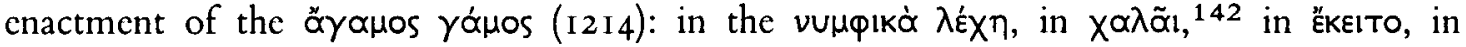

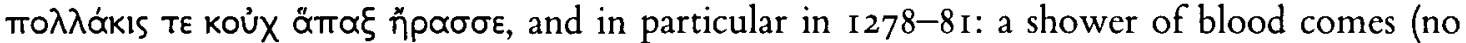
longer in separate drops but) all at once; the metaphorical हैpp $\omega \gamma \varepsilon v$ then proceeds naturally from the reality, as it too can refer to an outburst of liquid (a cloudburst, tears). ${ }^{143}$ Given the association between rain and semen, ${ }^{144}$ together with the description of what has burst forth as

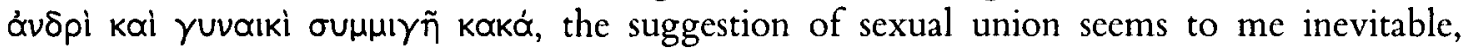
particularly as $\sigma \cup \mu \mu \varepsilon i \gamma \nu \cup \mu$ is a standard word for it. It is a pity that in his recent commentary Dawe not only fails to rectify the Victorian Jebb's omission of this point, but even removes one

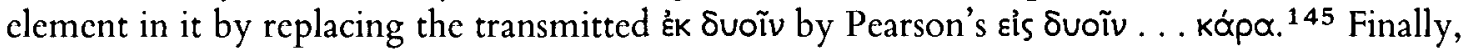
the ö $\lambda \beta$ os brought to Oedipus by his marriage, and which has now changed into its opposite

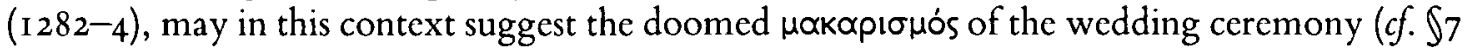
and $(\mathrm{I} 2) .{ }^{146}$

Two further points can be made in support of this conclusion. Firstly it has been reached quite independently of Freud's view of the self-blinding of Oedipus as a symbolic self-castration in which the eyes represent the genitals. ${ }^{147} \mathrm{I}$ am not concerned with the truth or falsity of this view. ${ }^{148}$ More to my point is the evidence adduced in its support by Devereux for the Greek association of eye and penis. ${ }^{149}$

Secondly we have already noted in various passages of tragedy that unity of opposites which associates the destruction of the body with the first physical union of the married couple $\left(\Omega_{4}\right.$ and n. 70 above). Particularly relevant here is the death of Haimon over the body of the hanged Antigone (S. Ant. 1237-4I): ${ }^{150}$

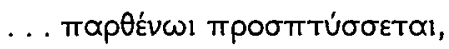

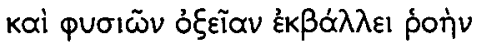

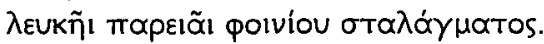

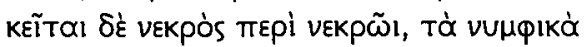

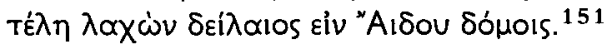

141 Bpux $7 \theta \varepsilon i$ ( 1265 ) on the other hand denotes an unrestrained noise associated with animals, and is used of Deianeira when she feels again the negative emotion of her wedding (S. Trach. 904; of. I071-2; Seaford [n. 33]).

${ }_{142}$ Cf. c.g. Od. xi 245; E. Tro. 50I, 665; Plut. L $y k$. I 5; and esp. S. Trach. 924. At Plut. Mor. $253 \mathrm{~d}$ a virgin undocs her $3 \omega v \eta$ and uses it as a noose for herself: this is interpreted by Helen King as an inversion of marriage and death (see $\$ 4$ and $n$. 8o).

143 Plut. Fab. I2; Ar. Nub. 378; Philostr. Im. ii 27; cf.

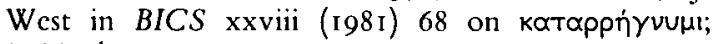
S. Trach. 852, 919.

144 Fertilising rain in c.g. A. fr. $44 \mathrm{R}$ (see above); Spóoos can mean drizzlc as well as semen (Dover on Ar. Nub. 977; Callim. fr. 260.19); the same association between rain, blood, and semen occurs also at A. $A g$.
I $388-92$ (see below).

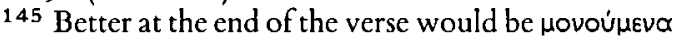

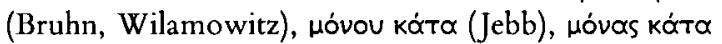
(Bruhn; cf. Thuc. i 32.5, 37.4; Pl. Leg. 873d).

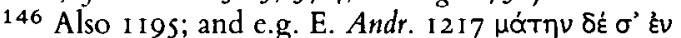

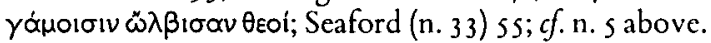
147 The interpretation of dreams (1935) 398.

148 Though of. the striking evidence adduced in its support by Devereux in $J H S$ xciii (1973), 36-49. Cf. R. G. A. Buxton in JHS c (1980) 25 .

${ }^{149}$ Devereux (n. I 48) 42, and Dreams in Greek tragedy, 33-6; notably representation of phalloi with eyes, and $P V 654$.

${ }^{150}$ Cf. also Trach. 917-I8, 924, 931, etc. (Seaford [n. 33], 57-8).

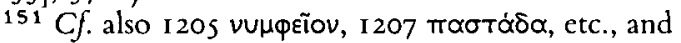
Si above. 
The same tómos is found also at A. Ag. I 389-92:

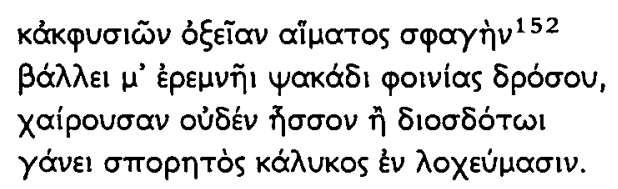

The similarity of wording with the death of Haimon is clear enough. And as in the blinding of Ocdipus, the comparison involves three terms: the blood is explicitly compared with rain,

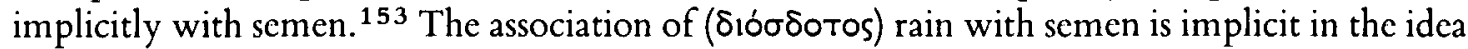
of the sexual union of Heaven and Earth, as in Aphrodite's speech from the Danaid trilogy ( $\mathrm{fr}$.

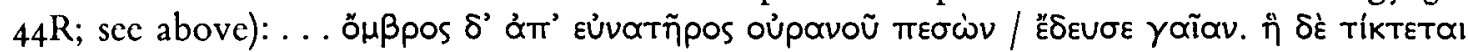
$\kappa \tau \lambda$. And this idea seems to have been a commonplace of the wedding ceremony, at least in antiquity. ${ }^{154}$

77. Euadne in Euripides' Supplices, dressed as a bride, sings a song which explicitly recalls her marriage and is itself suggestive of the wedding-song, and envisages her proposed suicide on the pyre of her husband Kapaneus as an erotic union. So much is clear enough, and well described by Collard. ${ }^{155}$ But certain further details in which the scene evokes the wedding remain to be cxposed.

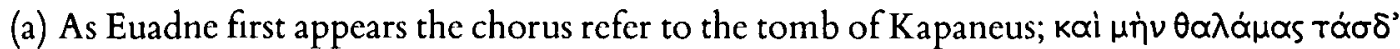

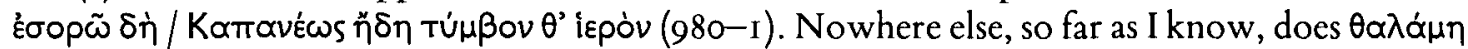
have any connection with death. Perhaps then it has here displaced $\theta \alpha \dot{\lambda} \lambda \alpha \mu{ }^{1},{ }^{156}$ which is clscwhere exploited for its ambiguity between tomb (or underworld) and marriagechamber. ${ }^{157}$

(b) Collard seems to me almost certainly right to suggest that the corrupt lines $992-3$

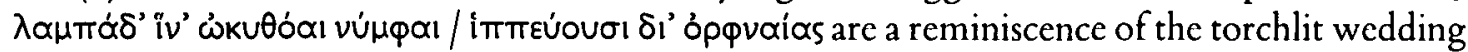
procession (of Euadne and Kapaneus). If so, then the point of $\omega$ kutó $\alpha,{ }^{158}$ which refers to the (presumably joyful) urgency of the procession, ${ }^{159}$ is an implicit association with the speed with

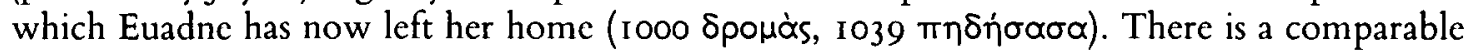

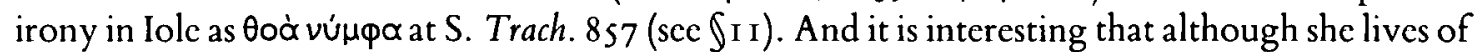
course in her husband's house (1097-8), she in fact leaves, as in her wedding, the house of her father (1038-42, I049). Similarly, the torches which contributed so much to the splendour of a wedding are associated with the fire in which she and her husband are now to be consumed. ${ }^{160}$

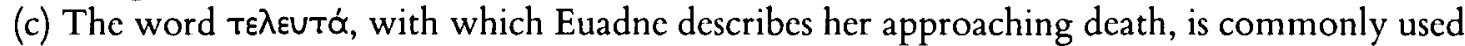

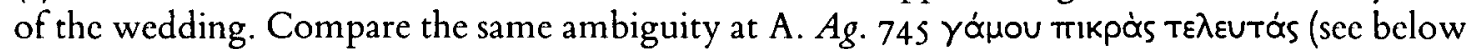
(9c). ${ }^{161}$

(d) After remembering her wedding

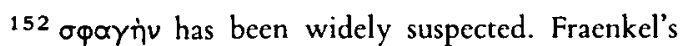
parjiv is in fact supported by the erotic undertone, which he ignores (see above on OT I 279 ĔppwyEv; West

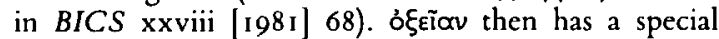
point, because a porýn may be $\gamma \lambda u k u ́ \pi$ ikpos (of semen) or painful (of blood). Cf. the similar common use of mikpós (esp. Seaford on Cyc. 589).

${ }_{153}$ The erotic undertone of this passage of $A g$. has always scemed to me clear, ignored though it is by the commentators. I now find it argued in detail by J. L. Moles (LCM iv 9 [1979] 179-89), who points to the

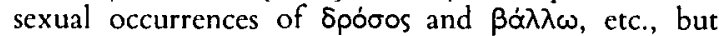
ignores the same tómos in S. Ant. and OT, as does G. J. P. O'Daly (Mus Helv. xlii [1985] 8) who is also I think

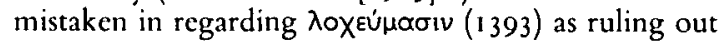
crotic associations.

154 Sce n. 117 above.

155 Commentary ii (Groningen I975) p. 358, Su. 9901030, 1063-71. Cf. also n. 76 above.

156 For the reverse displacement see E. Ba. 95, 561 .

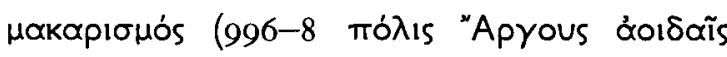

157 S. Ant. 947, 804 (cf. S. Trach. 9 1 3, El. 190; Seaford [n. 59] 3 I8); $f f$. E. $S u$. I022. Even if we keep $\theta \alpha \lambda \alpha \mu \alpha s$, there would surely be a play on $\theta \dot{\alpha} \lambda \alpha \mu \circ$ ( $f$. Collard).

158 Collard notes in his comm. that this word is transmitced paroxytone, incorrectly if the adj. is nom. plur., but perhaps a sign that the dat. sing. was at onc time understood.

159 Cf. Sappho fr. $44 \mathrm{~V} \mathrm{I} \mathrm{I,} \mathrm{23(?);} \mathrm{this} \mathrm{docs} \mathrm{not} \mathrm{mean}$

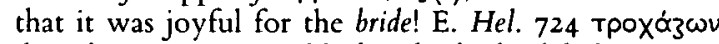
describes running quickly beside the bridal chariot.

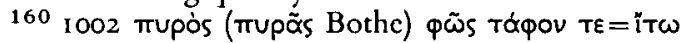

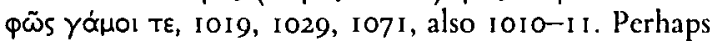
this association of celebratory and destructive fire gives

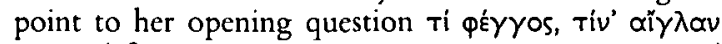

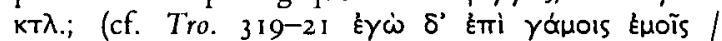

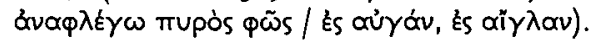

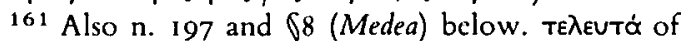
wedding also at A. Su. IOSO; Pi. Pyth. 9.66; Od. i $249-$ $50=x v i$ I $26-7$, xxiv I 26. 


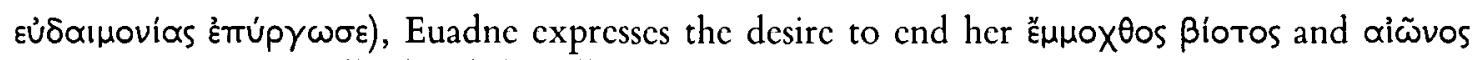
móvous (1003-s). Collard rightly calls this latter phrase an exaggeration ('Ev.'s whole life has not becn full of móvol, but only since the recent death of Cap.;). His explanation is that it is 'to suit the sententia 1006-8'. But in fact we should see it in the context of the failed wedding

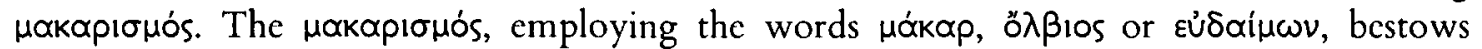
permanent felicity. ${ }^{162}$ But of course permanent happiness in life can never be safely predicted.

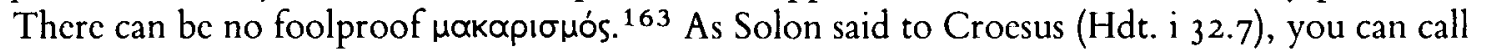
someone eỦTUXńs before he dies but not ö $\lambda \beta 105$; the latter depends on a successfully completed

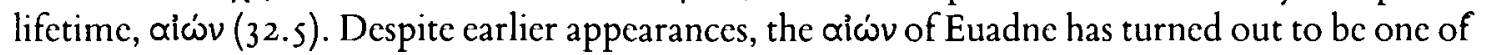
suffering. In the opening lines of Sophokles' Trachiniai Deianeira refers to the saying that you cannot cvaluate somebody's aív until he is dead; she on the other hand knows already that hers is bad, and goes on to explain how her married life has been one of constant suffering. ${ }^{164}$ Despite the sometimes apparently joyful tone of Euadne's song, she too, no less than Iokasta and

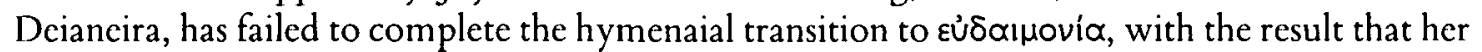
actual death is now imagined as a re-enactment of the wedding. ${ }^{165}$ Albcit in her case all that comes between husband and wife is the death of the husband.

$\int 8$. In despair at Jason's intention to marry Glauke, Euripides' Medea cxpresses a desirc for death. The chorus reply as follows (148-53):

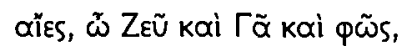

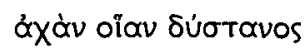

$$
\begin{aligned}
& \mu \varepsilon \hat{\lambda} \pi \tau \varepsilon \text { vú} \mu \varphi \propto ;
\end{aligned}
$$

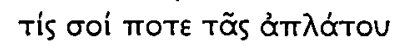

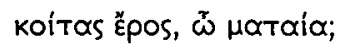

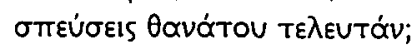

Four factors combine here to suggest the death-wish of a bride.

(a) As we have scen in Euripides' Suppliants and will see in Aeschylus' Agamemnon, the word

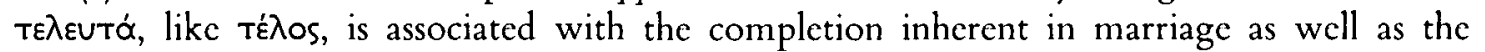
completion inherent in death. ${ }^{166} \mathrm{Wc}$ find the same ambiguity indeed later in the Medea (1388

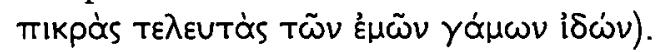

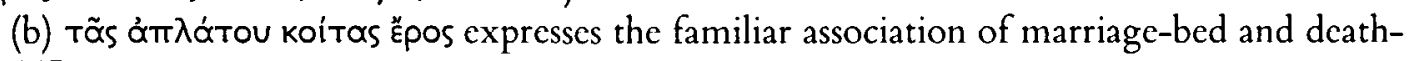

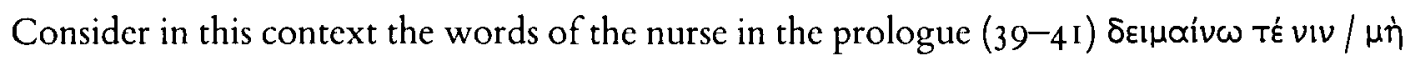

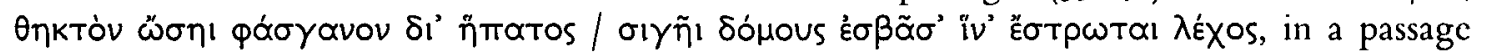
which is gencrally condemned. For example Dindorf, followed by Page and by Diggle, brackets $3^{8-43}$. The main reason ${ }^{168}$ for doing so is the repetition (with in for $\mu \eta$ and $\omega \sigma \omega$ for $\left.\omega \sigma \eta 1\right)$ of $40-\mathrm{I}$ at $379-8 \mathrm{o}$, in the deliberations of Medea on revenge. But the interpolation seems to me much more likely at $379-80$. If so, the original text there ran

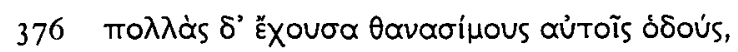

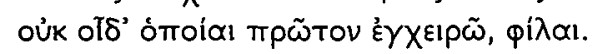

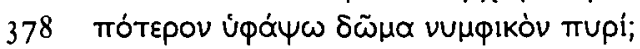

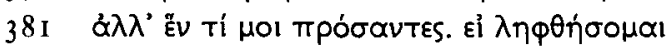

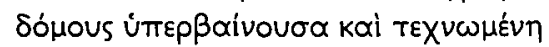

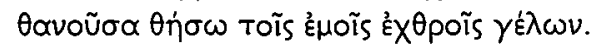

162 Sec c.g. Ar. Ran. I $182-6$, and in general D. de Hecr, MAKAP-EY $\triangle A I M \Omega N-O \wedge B I O \Sigma-E Y T Y X H \Sigma$ (Amsterdam 1969). Cf. n. $s$ above.

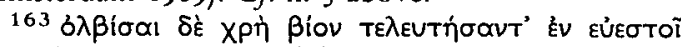
qi $\lambda \eta 1$ (A. Ag. 928-9). Cf. $\int 6$ and $\delta 12$.

164 Sec Scaford (n. 33).

165 That is why at 995 Collard is wrong to reject Haupt's aivo ${ }^{\prime} \mu \omega \nu$ on the grounds that 'discrepat cum gaudio Evadnae'.

166 E. Su. Iо I2; A. Ag. 745 ; and see n. I6r above.

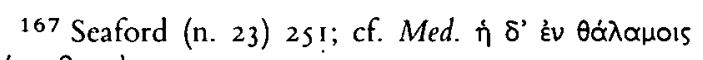

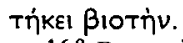

168 Page also objects to (a) î kai Túpowvov (42), and

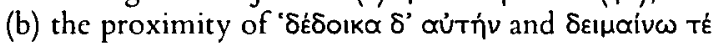

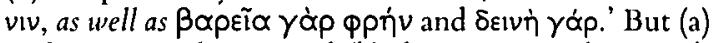
replace kai with тrंv, and (b) this expresses the nurse's anxiety. There may conceivably be radical corruption herc, but there are no good reasons for wholesale deletion. 


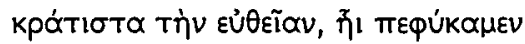

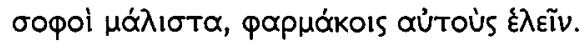

For the structure (mótepov . . . ; , then an objection, then an alternative) compare the words of the no less disturbed Iphigeneia (E. IT 884-9I):

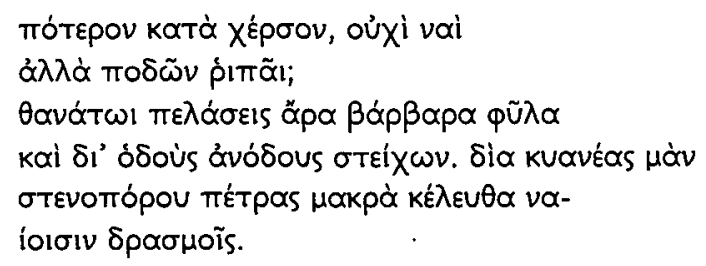

But the interpolator wanted to supply another alternative, immediately, with the usual ì after то́тєроv. He was influenced perhaps also by $\pi \circ \lambda \lambda \dot{\alpha}$ s $(376)$ and, in his choice of lines to interpolate, by $\delta \tilde{\omega} \mu \alpha \nu \cup \mu \varphi$ ı́̀े $(378)$. His interference is understandable, but it dilutes the point: Medea rules out the personal presence required by arson so as to choose the alternative of working from a distance with poison.

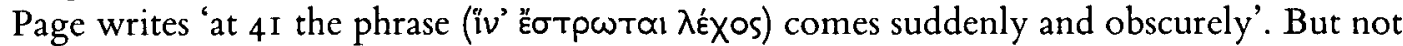
for those familiar with the Tómos of the wife's suicide with a sword on the marital bed. ${ }^{169}$ Here the tómos contains the extra pathos that the bed has been prepared to receive a new bride (Greek marriage is patrilocal). Page continues 'In 379 it is clear to whose heart $\delta \imath^{\prime} \eta^{\prime} \pi \alpha T o s$ refers: in 40 it is not so clear.' This is the reverse of the truth. It is clear enough in 40 from the tómos, and anyway Jason and Glauke are mentioned as an alternative in 42 ; whereas the omission at 379 is odd. 40-I make much better sense here than at 379-80. And Medea's very first words are indeed a wish to die (96-7; also $144-7$, etc.).

(c) $v \cup \dot{\mu} \mu \eta$ is used primarily of a young woman envisaged in relation to marriage, normally therefore of a bride, and although the designation may continue into the marriage (e.g. E. Or.

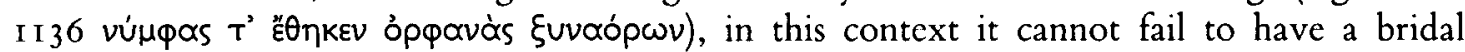
overtonc. ${ }^{170}$

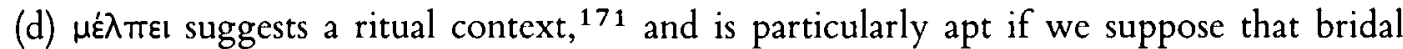
lamentation did occur in the wedding (see $\oint_{4}$ above).

Further examples might be described of the death of a wife imagined in terms of her wedding, notably Phaedra ${ }^{172}$ and Alcestis. ${ }^{173}$ But instead we will proceed to the next catcgory, in which an extramarital or merely natural union is imagined as a marriage in which the negative element prevails.

\section{The Extramarital Union}

99. At A. Ag. 685-762 the union of Paris and Helen is imagined by the chorus as a marriage which brings disaster. ${ }^{174}$ From the numerous elements of this picture I select six. ${ }^{175}$

169 S. Trach. 9I s-3 I (esp. 91 8, 920, 924, 930-I); V. Aen. iv 648-65; of. E. Alc. I 75-84; Winnington-Ingram (n. 23) $8 \mathrm{I}$ n. 28. For (apparently) abrupt statements of (other) Tómol see Seaford (n. 23) 249, 251; cf. n. 195 below.

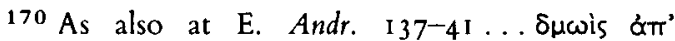

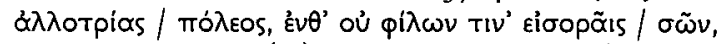

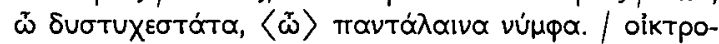

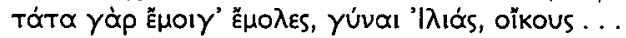

171 Page calls this a metaphorical use of $\mu \dot{\varepsilon} \lambda \pi \varepsilon v \nu$ very rare in tragedy, and compares A. $A g$. I445 and E. Andr. 1037 (both in fact of the lament).

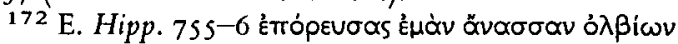

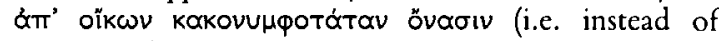

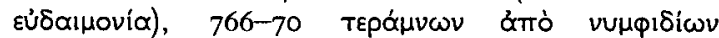

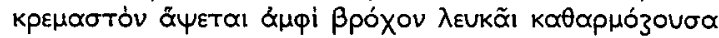

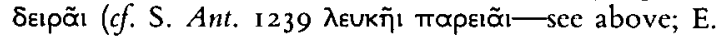

Med. I I 89, IA 875); for hanging as suicide v. Antigone, Iokasta, Erigone (imitated by Athenian virgins).

${ }^{173}$ E. Alc. $866-7,880-8 \mathrm{I}, 898,915-25$.

174 Given the tendency to describe adulterous union in terms of marriage ritual (cf. e.g. II I Iole, or the

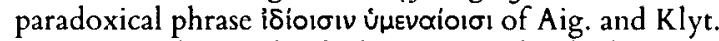
at E. Or. 558), it makes little sense to ask whether Paris and Helen were actually married or not (cf. Il. xxiv 763 , iii 140). Like the other cases in this category their union is extramarital in the sense that it violates the marriage of one of the partners, and 'natural' in the sense that it is effected by lust or violence or both.

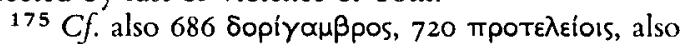

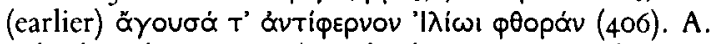
Lebeck, The Oresteia (Cambridge, Mass. 1971) 48-9, 69-7I, collects some of the obvious references to marriage in the trilogy. 


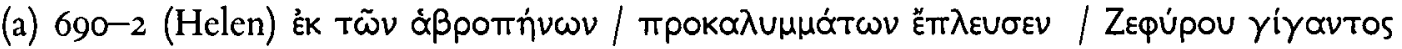

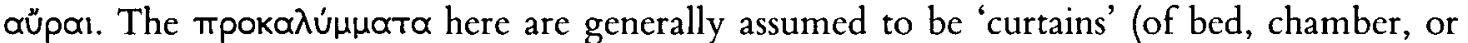
palace). But the reference is I think rather to the ritual unveiling of the bride. Nowhere else does

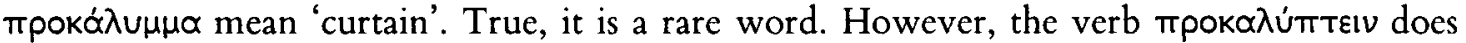
occur three times in tragedy: of the bride Glauke covering her eyes (E. Med. I 147), of Pylades covering Orestes with $\pi \dot{\varepsilon} \pi \lambda$ o (E. IT 3I2), and of Antigone casting off her veil in a passage containing hymenaial associations (E. Pho. I485-92, see n. I 85 below).

Furthermore, ká $\lambda \cup \mu \mu \alpha$ regularly refers to what covers the head, ${ }^{176}$ generally in the plural

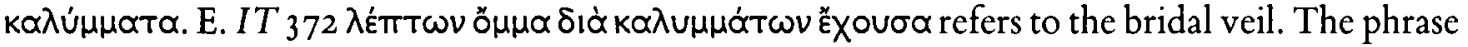

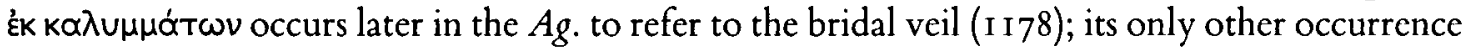
is at S. Trach. 1078, where I have argued (elsewhere) that there is a secondary allusion to the

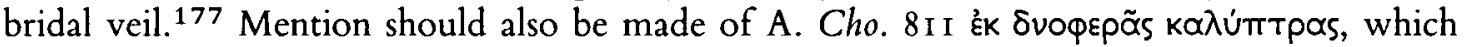
alludes to the ritual unveiling not of the bride but of the mystic initiand. ${ }^{178}$

It may be objected that 'she sailed from out of the veil' is an odd sense. But it is no more odd than 'she sailed from out of the curtains'. The abruptness may perhaps be explained in part by the

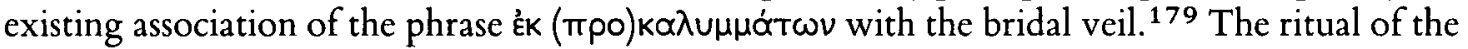
$\alpha v a k \alpha \lambda \cup \pi \tau n$ pı $\alpha$, the unveiling of the bride, seems to have occurred at the end of the wedding banquet, just before her departure on a chariot to her new home. ${ }^{\mathbf{1 8 0}}$

I suspect that this departure may have been associated with a nautical image. If so, the association would underly various passages of tragedy, for example ${ }^{181}$ (I) E. IT 370-I ÉV

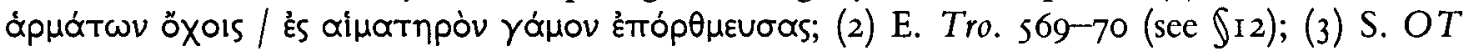

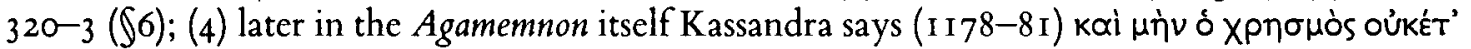

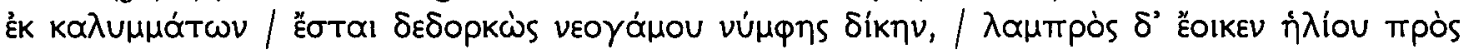

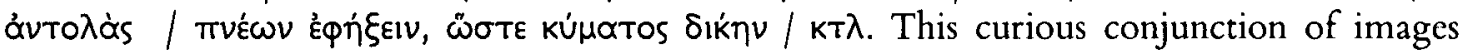
(unveiling, wind, and wave) cannot be explained merely by the multivalency of the word $\lambda \alpha \mu \pi \rho$ ós. ${ }^{182}$

At $690-2$, as at I I $78-8 \mathrm{I}$, we pass from unveiling to wind. Both passages are set in the context of the abduction of a woman (Helen, Cassandra - see $\int 10$ below), and at $69 \mathrm{I}$ है

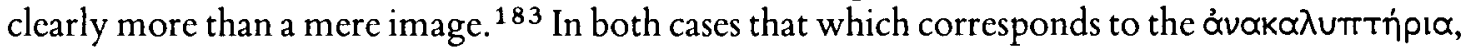
the sudden dissolution of contrived obscurity, is its opposite in mood: the discovery of the secret

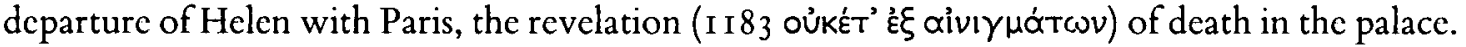
This irony occurs, I believe, in other plays: in the uncovering of the wounded Herakles towards the end of S. Trach., ${ }^{184}$ and in the unveiling, induced by grief, of Euripides' Antigone. ${ }^{185}$ But it occurs also elsewhere in the Agamemnon itself. It has been argued recently by M. L. Cunningham

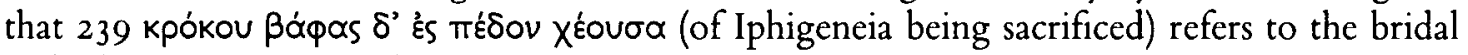
veil. She points in particular to the likelihood that the Greek bridal veil was saffron in colour, to

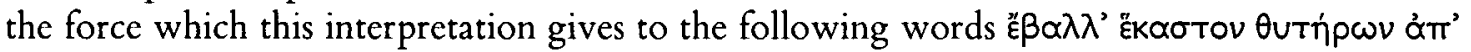

176 See LSJ. In both the apparent exceptions (A. Cho. 494; $S$. Trach 1078 ) it may in fact have the same sense ( $f$. Seaford [n. 23] 252-3, and [n. 33] 56-7.

177 (n. 33) $56-7$.

178 See G. Thomson in Comm. ad loc.; add Parmen. fr. I, Io (Thomson, The first philosophers [London I955] 289-9o).

179 For this kind of abruptness see n. I69 above.

$180 \mathrm{~J}$. H. Oakley in Arch. Anz. (1982) I13-14; J. Toutain in $R E A$ xlii (1940), 345-53. This fact underlics also $A g$. I 7 78-8 I (see below) and E. Pho. 1485-92 (see n. 185 below).

$181 \mathrm{Cf}$. the passages quoted in n. 183 below, also $\mathrm{A}$.

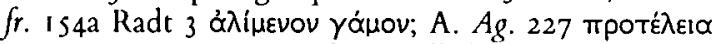
vaw̃v. Dionysos apparently travelled to his wedding at the Anthesteria in a ship cart: R. Seaford, Euripides Cyclops (Oxford 1984) 8 and n. 23.

182 'Clear' of oracles, 'bright' of the bride's com- plexion, 'keen' of the wind, and 'bright' of the sunlight: M. S. Silk, Interaction in poetic imagery (Cambridge 1974) 197; Simon Goldhill, Language, sexuality, narrative: the Oresteia (Cambridge 1984) 85 .

${ }^{183} C f$. the attention focussed on a sea voyage in a hymenaial context at E. IA 667-70, E. Hipp. $752-63$ (esp. 755-6, see n. I72 above), E. Tro. 455-6.

184 Seaford (n. 33) 56-7.

185 Pho. I485-92. She overcomes her maidenly

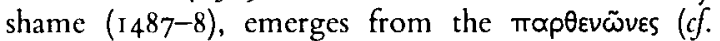
1275), sheds her veil, but is led not in a bridal profession

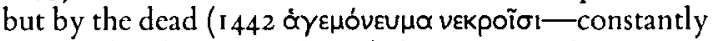
mistranslated as active). Cf also n. I 80 above. Her solitary, lamenting procession is similarly ambiguous (cf. $\mathbb{A}$ ) in Sophokles' version $\left(\mathrm{B}_{1}\right)$. This is not to ignore the influence of Hom. Il. xxii $468-72$ (also a wedding veil!). 


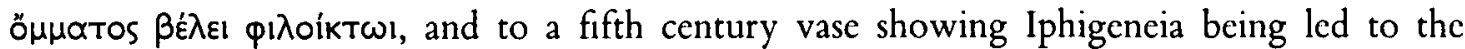
sacrifice holding up what seems to be a bridal veil. ${ }^{186}$ Four further points need to be madc. Firstly, the hymenaial association is in fact first introduced a little carlicr, in the description of the

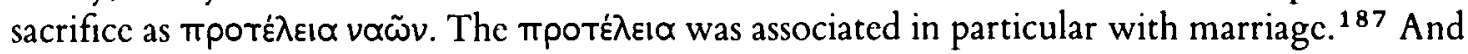
as we find elsewhere (see n. 198), the Aeschylean irony is made more explicit by Euripides (sec

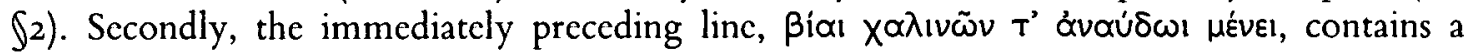
hymenaial image, the control over the bride as over an animal, ${ }^{188}$ which is picked up again at 244 with the description of Iphigeneia the virgin in her father's house as áraúpwtos. Thirdly, $\ddot{\varepsilon} \beta \propto \lambda \lambda \varepsilon \kappa T \lambda$. is of a very subtle pathos: the reversal of the mood of the wedding is perhaps not

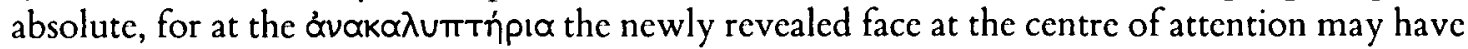

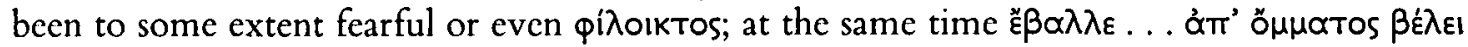
cannot fail in a hymenaial context to retain an erotic association, as does the phrase $\mu \alpha \lambda \theta \alpha$ aò

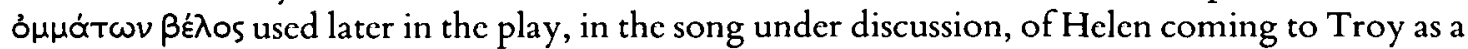
bride (742). ${ }^{189}$ Fourthly, this interpretation avoids the serious difficulties in interpreting крókou $\beta \dot{\alpha} \phi \alpha \mathrm{l}$ as blood or as the robe. ${ }^{190}$

As the song proceeds, other features of the marriage of Paris and Helen also turn into their opposite.

(b) The deity bringing the marriage to completion is not, as normally, Zeus TÉ $\lambda \in \operatorname{los}$, Hera

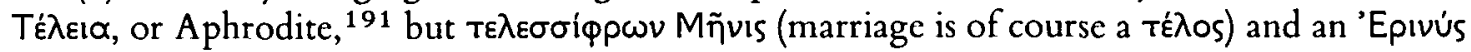
$(700,744-9)$. Indeed the common idea that deity is actually present at the wedding ${ }^{192}$ gives a special point to the presence of Mĩuls and the 'Epivús here.

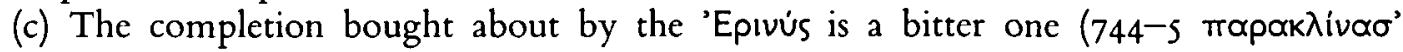

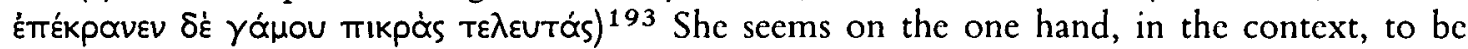

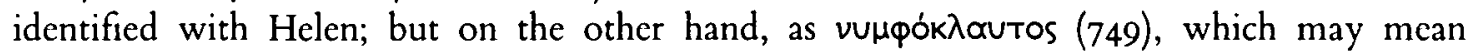
'bringing tears for the bride' or 'bewept by the bride' but hardly 'a weeping bride', ${ }^{194}$ she scems to be distinct from Helen. It seems best to allow Acschylus the sinister ambiguity. But whatever

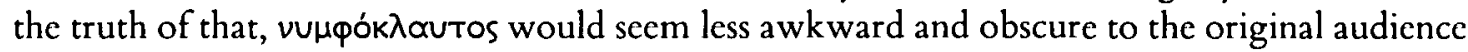
than it does to us, because for them it would evoke something familiar to the audience: ${ }^{195}$ the element of lamentation by or on behalf of the bride. ${ }^{196}$ Normally of course this negative

$186 \mathrm{M}$. L. Cunningham in BICS xxxi (1984) 9-12; $A R V^{2} 466$ n. 266. So too D. A. Armstrong and E. A. Ratchford in BICS xxxii (1985) I-I2, which appeared too late for consideration here.

187 Defined by Hsch. as of Helen in mpò $\tau \tilde{\omega} \nu \gamma \gamma \dot{\alpha} \mu \omega \nu$

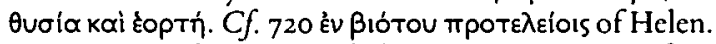
In $\mathrm{Ag} .65$ and 227 Fraenkel sees an inversion of its cheerful wedding associations. Similarly F. Zeitlin in $T A P A$ xcvi (1965) 465-6 ('unpropitious use'). Lebeck (n. I75) 186 , notes that 'it is precisely because she is sacrificed to Artemis that Iphigenia can be called

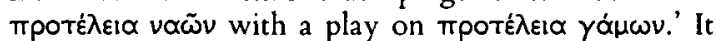
should be added that the story of this sacrifice had long been associated with marriage (see $\$ 2$ above). Further dimensions of (ironic) aptness are that the sacrifice of Iphigeneia is, like the marriage $\pi \rho \circ \operatorname{te}^{\lambda} \varepsilon ı \alpha$, a necessary prelude ( $c$. also $A g .65$ ) to a man (Menclaos) taking off

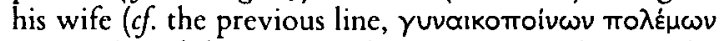

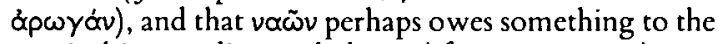
nautical image discussed above ( $f$. E. $I A$ 667-70).

188 See nn. 58 and 53 ; Sourvinou-Inwood, pp. I 37 ff, I 45 .

${ }^{189}$ Cf. also e.g. A. fr. $242 \mathrm{R} S u$. 1004-s; etc.: Thomson on PV $590^{-1}$ (his 6I4-Is), Barrett on E. Hipp. $525-6$ and $530-4$.

190 The slaughtering must come later; why nakedness?; etc. (see Lloyd-Jones in $C R$ ii [1952] 135-8; he suggests the robe hanging down to the ground). The objection to the robe might be avoided also by the view of C. Sourvinou (CQ xxi [197I] 339-42) that there is a reference to a (hypothetical) ritual derobing at the

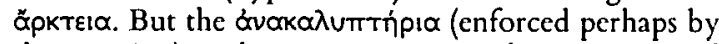
the gagging) makes more sense in the context, and unlike derobing would be consistent with Maas' view of

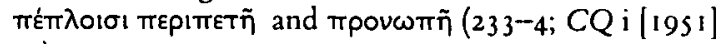
94).

191 A. Eum. 214 (cf. $A g .973$; F. Salviat in $B C H$ lxxxiv [1946] 647-54); Plut. Mor. 264b; D.S. v 73; Men. Rhet. 407.7; Ps. D.H. Epid. 262 Radermacher; $\delta$. also n. 94 above and n. 192 below. Cf. E. Hel. I 120-1 Mápis

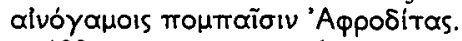

192 See nn. I I 4-I6 above.

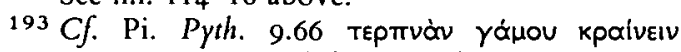

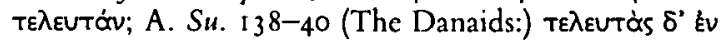

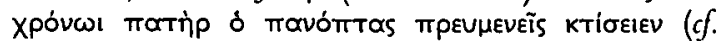

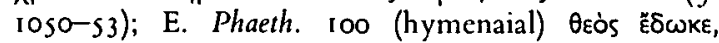

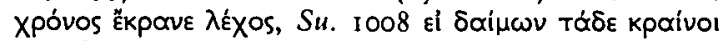
(see (7). At A. Ag. 70r we should read Headlam's ñvurev (see Thomson ad loc.).

$194 \mathrm{Sec}$ ad loc. Fraenkel, also Denniston-Pagc; also E. Hec. 948-9 (sec \I2).

195 For the critical principle involved see n. I69 above. Note also Fraenkel's remark (ad $A g$. 1278): 'Everything is compressed, hinting ... rather than describing fully. Time and again in Acschylus, above all in the Oresteia, do we encounter this "parodying" of sacred rites.'

196 See nn. 82-90 above. 
tendency would be overcome in the rite of passage. But here the deity who brings the marriage

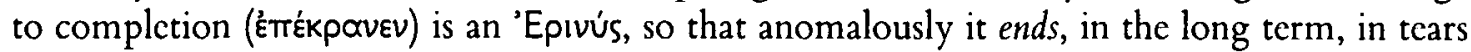

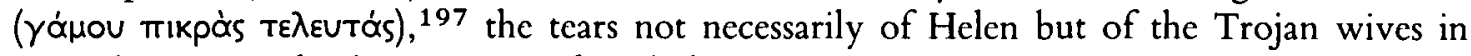

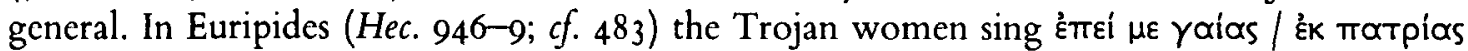

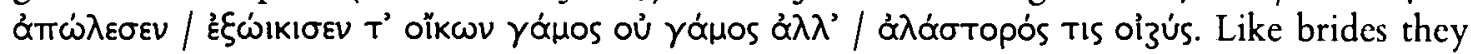
have been removed by marriage from their homes, but the marriage is not their own but Helen's and so not a marriage at all but suffering inflicted by an 'A $\lambda \dot{\alpha} \sigma \tau \omega \rho$. As at $A g .744-9$, it seems that a demon employs the marriage of Helen to inflict the subversion of marriage on the Trojan women. As elsewhere, ${ }^{198}$ Euripides makes more explicit the irony of Aeschylus.

(d) It has in fact been directly stated by the chorus that the Trojans, who earlier sang the wedding song, have now had to learn instead the song of lamentation (705-I6). At the wedding it is normal to compliment bride and bridegroom. ${ }^{199}$ Sophokles applies the word eữekTpos to the bride (Ant. 796), and to Aphrodite at the contest for the vú $\mu \propto \alpha$ Deianeira (Trach. SIs). But

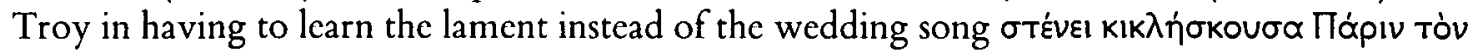

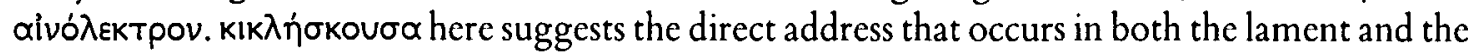
wedding song. ${ }^{200}$ There may also perhaps be a faint suggestion of the funcrary $\lambda$ ékтро৩. ${ }^{201}$

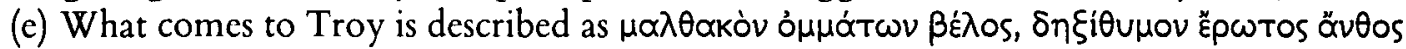
$(742-3)$. The image of the flower is traditionally applied to the bride in the wedding. ${ }^{202}$ In Acschylus' Suppliants it is associated simultaneously with the unwilling brides and the young men threatened by war $(663-6, \$ 4)$. Here the words $\beta \dot{\varepsilon} \lambda$ os and $\delta \eta \xi i \theta u \mu o v$ are appropriate to the praise of the beauty of Helen (sec Fraenkel ad loc.), but acquire in the context a sinister double mcaning.

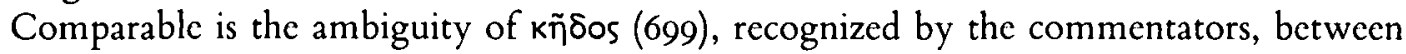
connection by marriage and grief. It is of interest to compare also Euripides Phoenissai $34^{0-3}$,

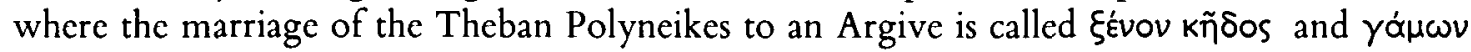

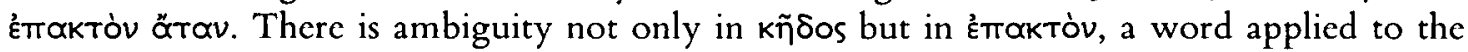
wealth brought by a wife to the home of her husband (E. fr. 502.5), but which has two extra senses here: firstly, the bride comes not just from another household but from another city; and sccondly ÉTakтós in Aeschylus refers to the foreign army brought by Polyneikes, ${ }^{203}$ and so cannot fail to suggest here the connection between the marriage of Polyneikes to an Argive and the Argive invasion of Thebes. And when Jokasta goes on to complain that the marriage was not

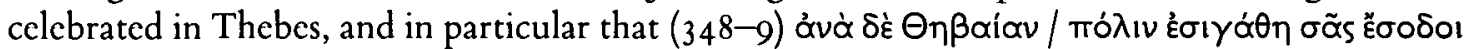

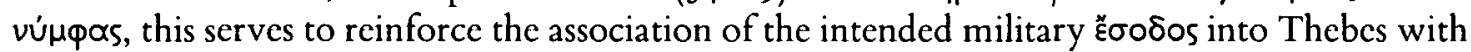
a bridal procession.

(f) The dire consequences of the impious union between Helen and Paris are described as offspring (750-70). Here too we find, it seems, the perversion of a wedding tómos, the desire for children resembling their parents. ${ }^{204}$ This gives a special point to $758-60$ tó $\delta \cup \sigma \sigma \varepsilon \beta \dot{\varepsilon} s \gamma \alpha \dot{\alpha}$

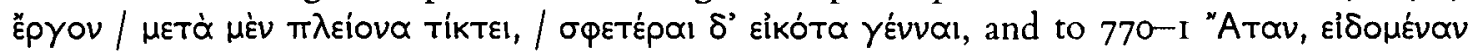
TOKEบ̃oIV.

To conclude, $A g .690-771$ exhibit a multiple perversion of wedding ritual, in which the

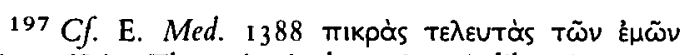

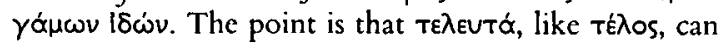
refer both to marriage and death: n. I66 above; E. Med. I 53 ; cf. e.g. Artemid. Oneir. ii 49.

198 Seaford (n. 23) 248.

199 E.g. Sappho frr. I08, I 10, I I I, I I2, I I5, I I6; Ar. Pax 1349-50; E. Alc. 920-1; Theocr. 18.19-38, 49; Men. Rhet. 402.22-404.14; Gregor. Naz. PG xxxvii I 493-5.

200 Il. xxiv 725, 748, 762; A. Ag. 315; E. Tro. I16772; Sappho frr. 108, II2, II3, I Is, II6, I17; Ar. Pax I 344-6; Catull. 62.59; etc.

${ }^{201} \mathrm{Cf}$. the same irony at A. $\mathrm{Ag} \cdot$ 1440-I (quoted $^{2}$ below, $(10)$ and Bion I.70; f. e.g. A. Cho. 3 1 8; E. Hel. $126 \mathrm{I}$; and in general Seaford (n. 23) $25 \mathrm{I}$ (on $A g .11 \mathrm{1} 6$ );

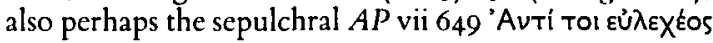
$\theta \alpha \lambda \alpha \dot{\alpha} \mu \mathrm{ov} . .$.

202 See above $\oint_{4}$ and nn. 61-4.

${ }^{203}$ Sept. 583; ff. c.g. S. Trach. 259, OC 525; cf. E. Pho. $580-2$.

204 Emphasised by Men. Rhet. 404.27, 407.9, 23; Catull. 61.2I4-I8; if. Theocr. I8.21, 50-53; Sidon. Apoll. Carm. I 5.19I; Ps. D.H. Epid. 266. Cf. also Hes. Op. 235 and West ad loc. (add. Pl. Crit. I $12 \mathrm{c}$ and Plut. Mor. 824C). 
positive elements are perverted into negative elements and the negative elements prevail. Comparable, in microcosm, is Sophokles' Elektra 193-9:

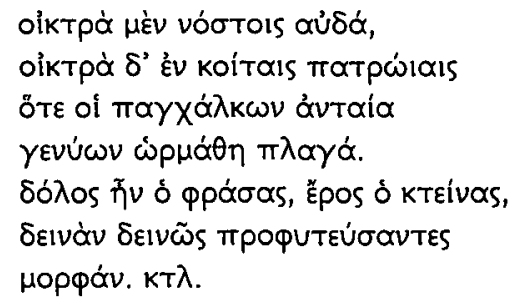

Here the homecoming of Agamemnon and his death at the hands of Klytaimestra and Aigisthos

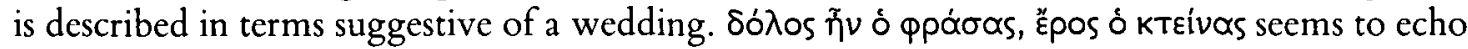

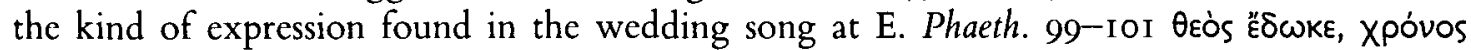

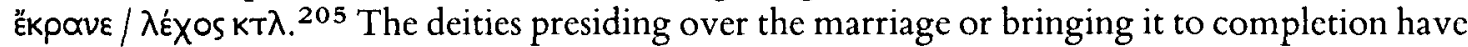

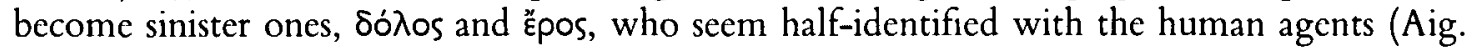
and Klyt.), ${ }^{206}$ and give birth through a terrible breeding to terrible offspring (the murder). "Epos is of course not inappropriate to a normal marriage, ${ }^{207}$ but here assumes a sinister function. The reunion of husband and wife $\mathrm{e}^{208}$ becomes the occasion for murder by the united wife and lover. Two further elements complete the picture. By an irony that should by now be

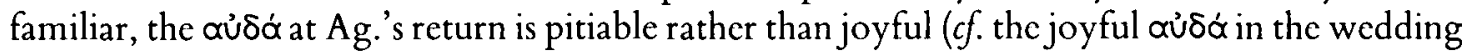

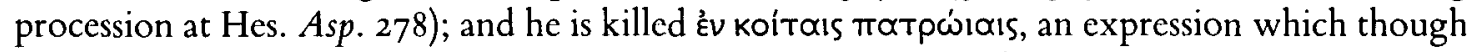
consistent with the tradition that Ag. was killed at a banquet $(c f .203-4)$ cannot fail to suggest here a marriage bed. ${ }^{209}$ Every one of these ironies has its counterpart in A. Ag. 690-77I.

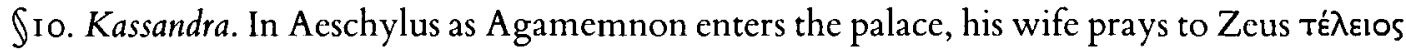
(973), the 'accomplisher'. She wishes Zeus to bring her prayers to completion (ràs ह̇uàs eưxàs

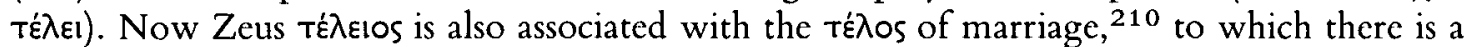
sccondary reference here. The death of Agamemnon is envisaged as a kind of marriage, which

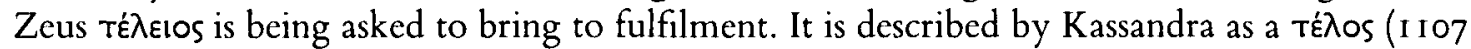

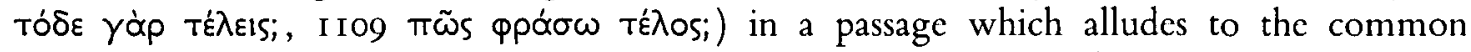
association between death and marriage, ${ }^{211}$ and by Klytaimestra herself in terms which allude to

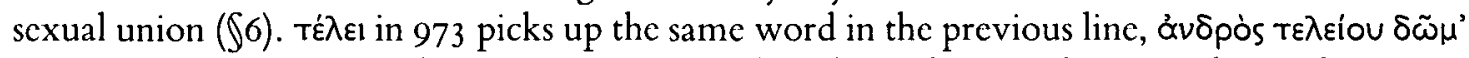

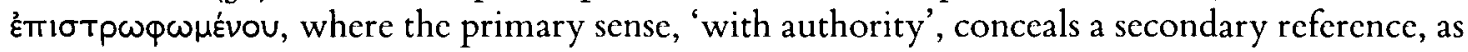

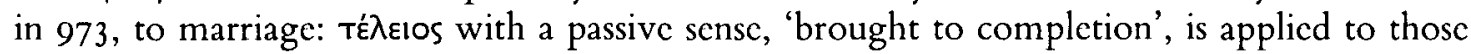
who have entered on marriage. ${ }^{212}$

Interpenetrating this grotesque union of Agamemnon with Klytaimestra is the no less grotesque union in death of Agamemnon and Kassandra. As in the Trachiniai ( $(S 5$ and $\ \mathrm{II}$ ) and the Medea ( $\$ 3$ and $\$ 8$ ) the husband's new attachment creates a situation in which the mutual subversion of the two incompatible unions issues in the death of one or more of the three partics. Klytaimestra describes the dead Kassandra, displayed alongside the corpse of Agamemnon, ${ }^{213}$ as

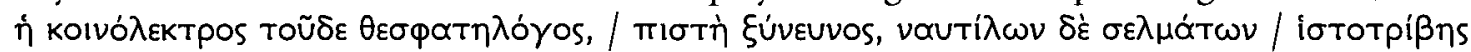

${ }^{205}$ Cf. also Men. Rhet. 400. I 8-20, 406.22-4; on the origin of this style in ritual formulae see $\mathrm{G}$. Thomson in JHS lxxiii (1953) 82-3; cf. esp. Zenob. Prov. iii 98.

206 Jebb compares Klyt. as ád $\alpha$ otw We of course think of Helen as 'Epivús at 737-49.

207 E.g. Men. Rhet. 404-20, 407.19, 411.13.

208 This bloody reunion is envisaged as a grotesque marriage by Aeschylus (see $\ \mathrm{I} 0$ ).

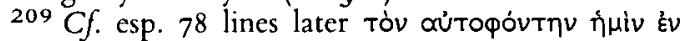

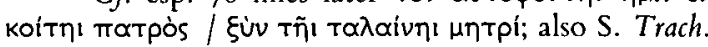
922; etc. (LSJ).

210 Schol. Ar. Thesm. 973; D.S. 5.73; Plut. Mor. 264 b; cf. esp. A. Eum. 2 I 4 ; in general see F. Salviat in
$B C H$ lxxxiv (1946), 647-54, who sees a ref. to marriage in $A g .973$, but regards the point as being that Zcus in his association with marriage is the right deity to pursue a wicked father or husband. See also Lebeck (n. 175) 6873 .

211 Cf. Seaford (n. 23) 251.

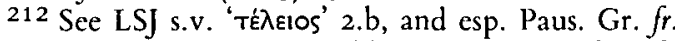

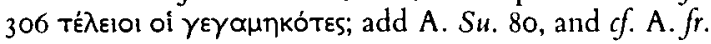
44.7.

213 I suspect that she appeared wrapped with $\mathrm{Ag}$. in the fatal cloth ( 1492, I 580 ), and therefore huddled in the bath ( 1540$)$, which is described as a bed on the ground

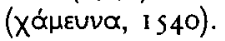




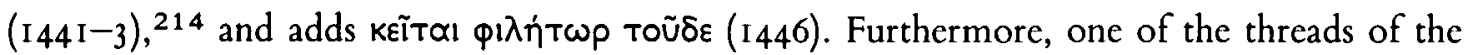
famous 'Kassandra scene' is a sustained evocation of the negative elements in the situation of a bride: (a) like the bride, Kassandra has been taken from her father's home ${ }^{215}$ and has arrived in a chariot with her man at his home; ${ }^{216}$ (b) like the bride (apparently), she laments (1 322); ${ }^{217}$ (c) whereas for the bride capture and death are at most fictions, ${ }^{218}$ for Kassandra they are a reality; (d) the bride was apparently welcomed on arrival outside her new home; ${ }^{219}$ in attempting to

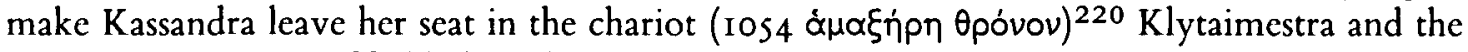
chorus use persuasion; ${ }^{221}$ (e) they also compare her to an animal newly caught or unwilling to bear the bridle or the yoke; ${ }^{222}$ (f) the image Kassandra employs to express the emergence of her speech out of deliberate obscurity, the image of the unveiling of the bride (I I $78-83$, sec $\$ 9$ above), is therefore not chosen arbitrarily.

This implicit allusion by Aeschylus to ritual is, as elsewhere, ${ }^{223}$ made explicit by Euripides. Kassandra in the Trojan Women enters with a wedding torch (or two) and sings a wedding song $(308-52)$. Kassandra is herself of course aware that the destination of the transition is Hades, ${ }^{224}$

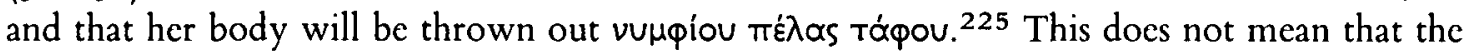

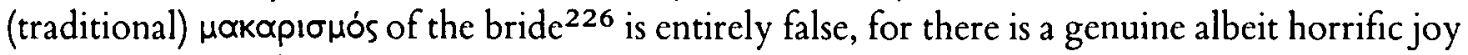
at the prospect of the death of her $\gamma \propto \mu$ étas that will accompany her own. ${ }^{227}$ It is perhaps an exact reversal of normal practice firstly that the (inspired) bride takes the initiative $(308,325$,

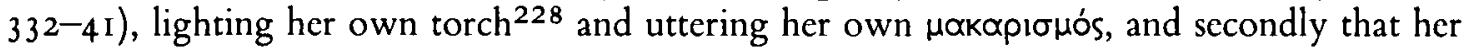
joyful singing contrasts with the lamentation of everybody else $\left(3 \mathrm{I}_{5}-19,332,35 \mathrm{I}-2\right)$. Certainly her mother envisages the torch as funereal, ${ }^{229}$ an ambiguity well known from the Anthology. 230

II I. Iole. On discovering that Herakles is about to return home the women of Trachis sing

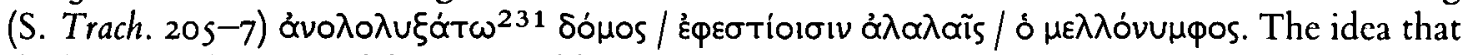
the house is about to celebrate a wedding has of course offended some textual critics. But it is in fact, as I have argued in detail elsewhere, ${ }^{232}$ one of a coherent series of allusions to wedding ritual throughout the play, some of which I have mentioned in $\$ s$ above. The return of Herakles is envisaged here as the re-enactment or final completion of the marital transition of Deianeira. But at the end of the song there arrives at the house a group of female captives, one of whom is noticed from among the others ${ }^{\mathbf{2 3 3}}$ by Deianeira, who remarks on her apparent virginity

214 To the defence of iototpißns (with an erotic sensc) by Douglas Young (in CQ xiv [1964] I5) add A.

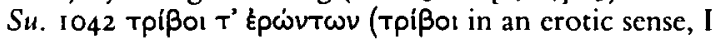
believe, and a hymenaial context: $\$ 4$ ).

215 Note the stress on the paternal home left behind

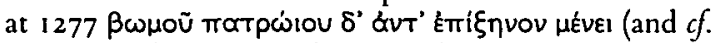

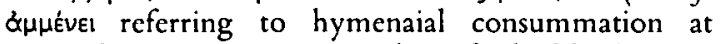
S. Trach. 528; E. C $\gamma$ c. 514 with Seaford ad loc.).

216 I find the suggestion that "the arrival of Agamemnon and Cassandra like a bride and groom at the door when Clytemnestra stands waiting to welcome her husband home has a blatant irony' made independently by Ian Jenkins [n. 3] I 38) on the basis of the fact that 'Agamemnon's arrival at the palace on a chariot with Cassandra by his side, and Clytemnestra waiting to grect them, corresponds pictorially with the vasepainter's formula for the arrival of bride and groom.' He refers to O. Taplin, The stagecraft of Aeschylus (Oxford 1977) 302-6, who successfully argues that $\mathrm{Ag}$. and Kass. were in the same chariot.

217 Cf. above nn. 3, 82-92.

$218 \mathrm{Cf}$. above nn. 4, 68-9.

219 Schol. E. Pho. 344; Jenkins (n. 3) continues 'The position of Clytemnestra at the doorway of the house is that occupied by the groom's mother in the vase seenes of bride-fetching.'

220 The bride had a special seat in the chariot: Hsch.

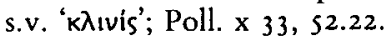

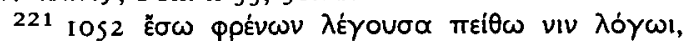

I049, 1054. $C f$. persuasion in the wedding: $\oint_{4}$ and $n$. 94 .

$2221048,1063,1066,1071 ; c f . \$_{4}$ and $n .58$.

223 See $\$ 9 a$, \$9c, and n. 198.

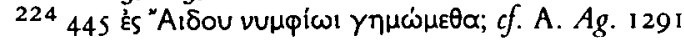

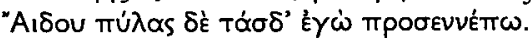

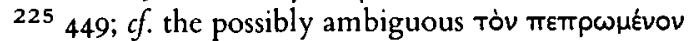

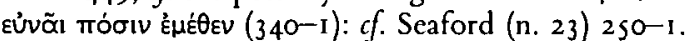

226 312-I3; cf. 3II, 327, 336, 366; of. n. s above.

2273 I I, 356-62, etc.; also at other Argive and Greck sufferings: $363 \mathrm{ff}$.

228308,$320 ; c f$. e.g. E. Phoen. $344-6, I A 732$. So far as I know the bride never carries a torch in vase-painting.

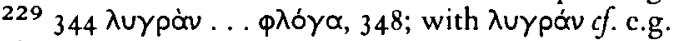

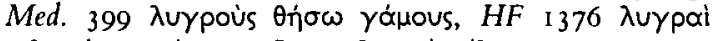

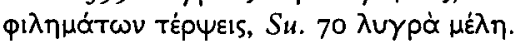

230 e.g. $A P$ vii I 85 (sepulchral): Tũ

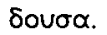

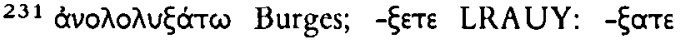
$\mathrm{KZg}$.

232 (n. 23).

233 of. Theocr. I 8.25-8; Sappho fr. $34 \mathrm{~V}$. 
(ämeıpos) and nobility (307-I3). This is Iole, the bride 234 of Herakles. Deianeira is, without yet realising it, in the position of Klytaimestra, standing in front of the house to which the new bride

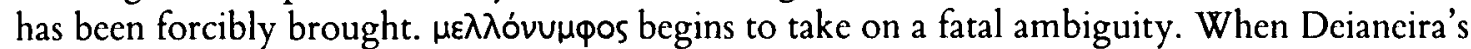
suspicions are subsequently aroused, she praises her again, this time for her beauty (379). ${ }^{235}$

Later in the play the chorus, reflecting on the origin of Herakles' sufferings, mention his

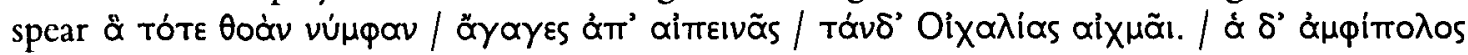

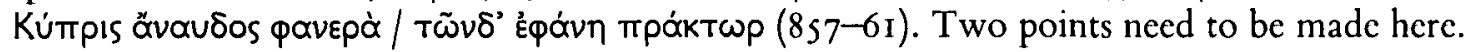
Firstly, Өod̀ is emended away by some, and defended by others as meaning 'swiftly'. Both

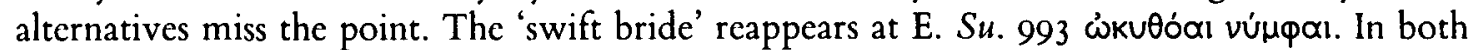
cases there is a poignant association between the urgency of the wedding procession which onds happily and the present arrival of the bride $(\$ 7)$. Euadne comes quickly to her husband's pyre. Iole is seized with ruthless urgency from her father's home; and the speed of her arrival is

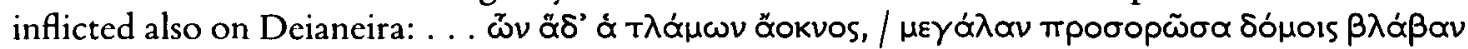

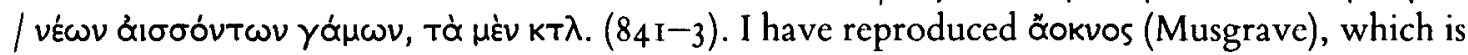
generally accepted. But the mss. öokvov may be right. Iole will not be allowed to delay her

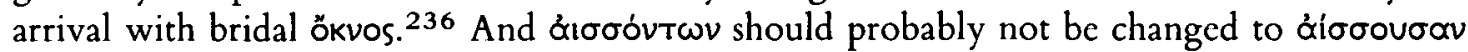
(Nauck). $\pi \rho \circ \sigma \circ p \tilde{\omega} \sigma \alpha$ suggests actual visual perception, ${ }^{237}$ and evokes therefore the position of those waiting at the house of the groom for the bridal procession.

Secondly, the sinister epiphanic role of Aphrodite (860-I), expressing the destructive carnality of this union, is given special point by her (silent) presence even at a normal wedding. ${ }^{238}$ She plays a similar role in Euripides' description in the Hippolytus ${ }^{239}$ of the brutal 'wedding' of Herakles and Iole. In the Agamemnon the deities bringing the union of Helen and Paris to completion are a Mñuls and an 'Epivús (\$9b). An 'Eplvús is present at the union of

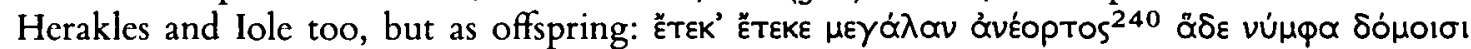
тоĩ $\delta^{\prime}$ 'Epivu'v (893-5). This is comparable to the perversion we found in the Agamemnon of the desire expressed at the wedding for children resembling their parents ( $(9 \mathrm{~g})$.

I12. Andromache opens the play of Euripides that bears her name by calling on the city of her

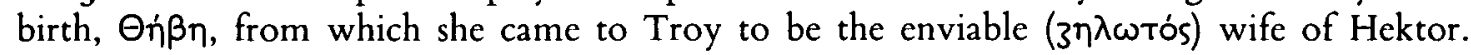
Somewhat later, lamenting the loss of her city and her husband, and her consequent yoking

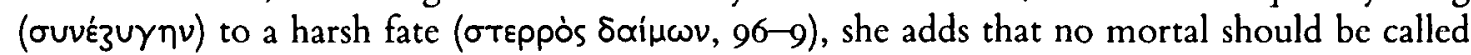
ö $\lambda$ ııs while still alive (IoO-2), a proverb which in this context must suggest the failed

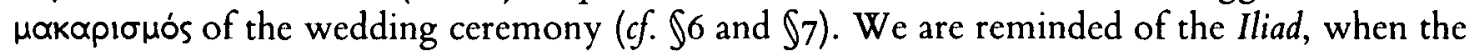

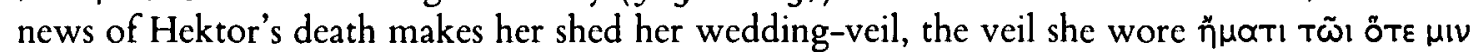

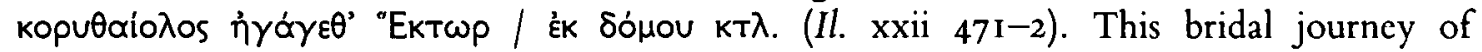
Andromache was described in rich detail by Sappho, and may even have been paradigmatic. ${ }^{241}$

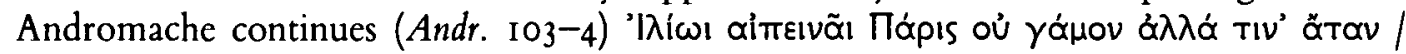

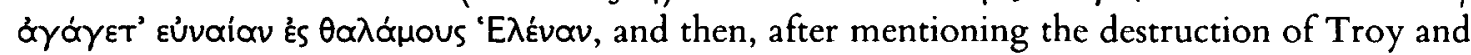

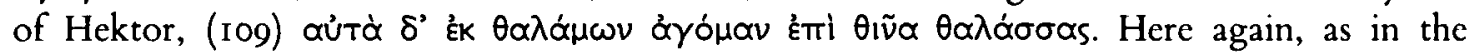
Agamemnon and the Hecuba $(\mathbb{9 c})$, the 'marriage' of Helen and Paris is associated both with a destructive deity and with a Trojan marriage that it has destroyed. Whereas at Hec. 946-9 the Trojan brides are taken by marriage from their homes, but the marriage is Helen's, here in the Andromache it is as if one bridal journey to Troy (Helen's) has put another (Andromache's) into

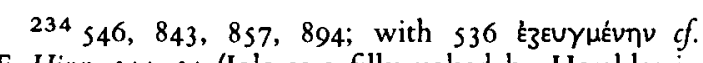
E. Hipp. $544^{-54}$ (Iole as a filly yoked by Herakles in marriage).

235 For praise of the bride (usually for beauty) see n. 202.

236 See in detail Seaford (n. 33).

237 mpooopõv generally refers to actual seeing; the only possible exception in Soph. is at OC 142. Cf. Trach.

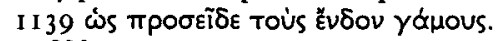

238 nn. $114-16$.

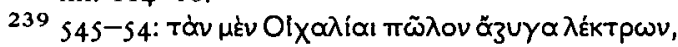

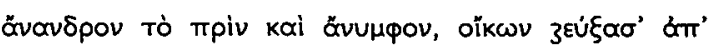

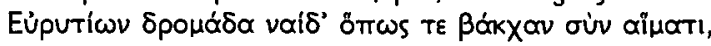

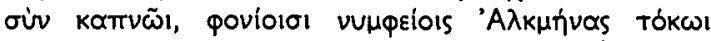

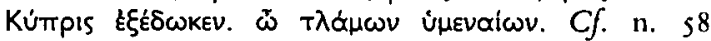
(yoking) and, on the bride as maenad, E. Su. 1000-01 (\$7) and Tro. 307,342 , etc. (\$10).

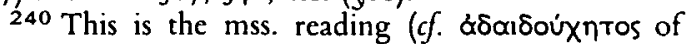
clandestine marriage). \& véopтos is generally printed.

241 Sappho fr. 44 (composed perhaps to celebrate a real wedding). 


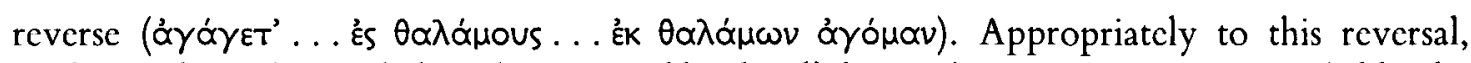

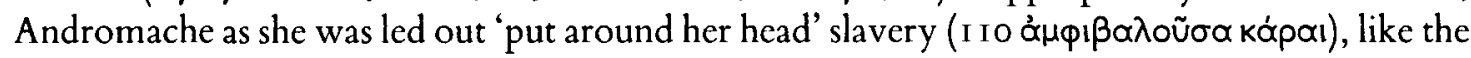
veil normally shed by the departing bride. A little later the chorus sing of Andromache's

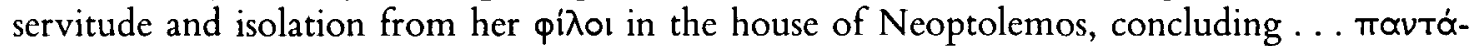

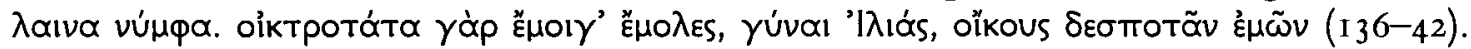
The idea of the departure of the bride as physical abduction $(\$ 4$ and $n .3$; note especially Catull. 62.24 quid faciunt hostes capta crudelius urbe?) facilitates the implicit association here of the abduction of Andromache with marriage. So it is also with Kassandra and Iole (see above), and

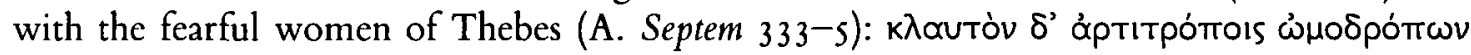

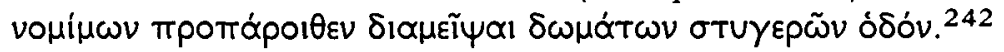

The idea of Andromache's departure from Troy as a perverted bridal journey reappears in

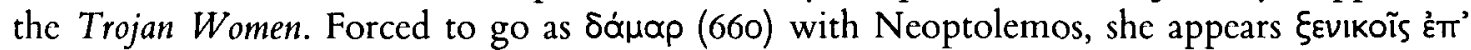

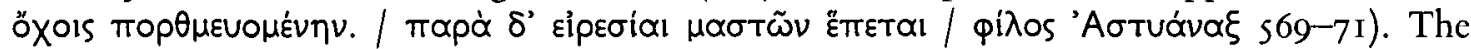

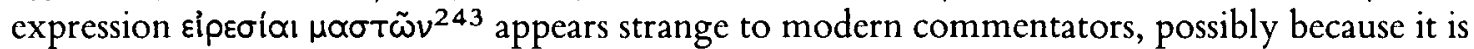
an ironic development of the idea, familiar perhaps to the original audience, of the bridal cart as a boat $(\$ 9 a) .{ }^{244}$ Andromache is $\pi \alpha \dot{\alpha} \rho \delta \rho \rho$ not, as in a bridal journey, to her husband, but to her dead husband's weapons ( 573$)$. She calls on him to come, but is told that he is in Hades $(587-8)$; and so she asks to be taken to Hades herself (594). ${ }^{245}$ Finally, she reflects on the prospect of union

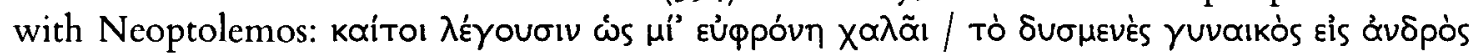
$\lambda \dot{x} \chi 05(665-6)$. This is a sentiment associated with marriage in general: $c f$. Sophokles $f r .583$, of

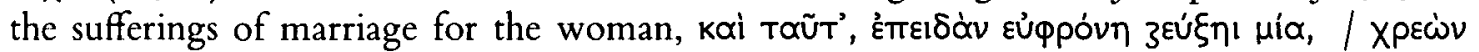

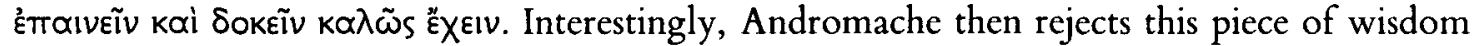
with an image usually used to legitimate the subordination of the bride, the image of the yoked

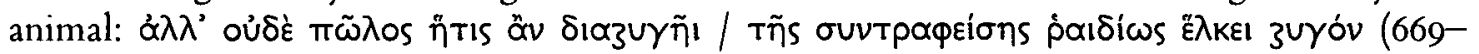
$70) .{ }^{246} \mathrm{We}$ noticed in Aeschylus' Suppliants a similar reversal of hymenaial imagery by women resisting marriage $(\$ 4)$.

\section{The University of Exeter}

242 The text is here disputed (I give the main mss. tradition), with suggestions including \&ptıтрópors,

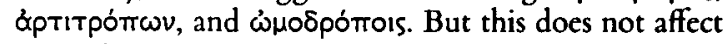
my point.

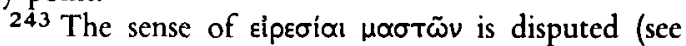
K. H. Lee in Philologus cxvii [1973] $246 \mathrm{ff}$ ); but this does not affect my point.

\section{RichaRd SEAFORD}

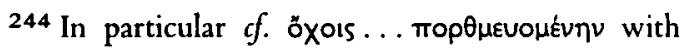

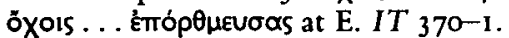

245 On the bridal journey imagined as to Hades see Jenkins (n. 3).

${ }^{246} \mathrm{Cf}$. Andr. 98 (quoted above) and 178 ; also n. 58 above.
} 